\begin{tabular}{|c|c|}
\hline $\begin{array}{l}\text { Web Revista } \\
\text { 0.GLIALET0 }\end{array}$ & 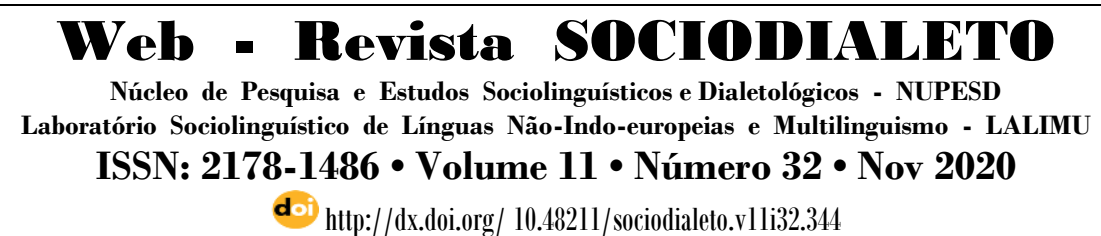 \\
\hline
\end{tabular}

\title{
"POLONÊS É BONITO, MAS AQUI SE FALA BRASILEIRO" - ATITUDES LINGUÍSTICAS COM RELAÇÃO À LÍNGUA POLONESA E SUA MANUTENÇÃO
}

\author{
Alicja Maria Goczyla Ferreira (UFPR) \\ alicja.ferreira@ufpr.br
}

\begin{abstract}
RESUMO: Este artigo apresenta resultados de uma pesquisa de atitudes linguísticas com relação à língua polonesa e a sua manutenção em uma colônia de polono-descendentes no Paraná. Os objetivos são 1) averiguar como os informantes percebem a língua polonesa padrão e a variedade local e 2) como as suas atitudes se relacionam com variáveis tais como a competência na língua local e os comportamentos referentes à sua manutenção. Os dados analisados nesta pesquisa foram levantados em uma pesquisa sociolinguística anterior, a qual, por meio de conversas semidirigidas com 48 informantes de ascendência polonesa, concluiu a existência de bilinguismo na comunidade sendo que $56 \%$ de informantes demonstram um bom domínio da língua polonesa. No entanto, as taxas decrescentes de transmissão da língua de imigração indicam um avançado processo de substituição da língua polonesa na localidade, o que nos levou a um estudo pormenorizado das atitudes linguísticas. Esta pesquisa de atitudes linguísticas (BAKER, 1992; VENDERMEEREN, 2005) constatou a existência de uma possível relação entre, por um lado, as crenças relativas à gramaticalidade da língua e da sua função como depositária de cultura e de origem dos informantes e, por outro lado, seus comportamentos linguísticos, tais como a transmissão da língua para as gerações mais novas.
\end{abstract}

PALAVRAS-CHAVE: Atitudes linguísticas; Línguas de imigração; Língua polonesa no Brasil.

\begin{abstract}
This paper presents the results of the language attitudes research concerning Polish language and its maintenance in a Polish descendants' rural community in the state of Paraná, Brazil. It aims to observe 1) how the informants perceive the Polish standard language and the local variety and 2) what is the relation between their attitudes and variables such as language competence and behaviours concerning the language maintenance. The data used in this paper were collected for prior sociolinguistic research, which, by means of semidirected interviews with 48 informants of Polish descent, confirmed the existence of bilingualism in the community and stated that $56 \%$ of the research participants can speak well the local variety. Nevertheless, the decreasing language transmission rates indicate an advanced language shift process, which triggered us to this more detailed analysis of language attitudes. This language attitudes research (BAKER, 1992; VANDERMEEREN, 2005) established that the informants' beliefs about the correctness and cultural value of the language are possibly related to their behaviours, such as language transmission to the younger generations.
\end{abstract}

KEYWORDS: Language attitudes; Immigration languages; Polish language in Brazil.

\section{Introdução}

Entre centenas de línguas faladas no território brasileiro, as quais compõem a rica paisagem linguística do nosso país, ouvem-se sons sibilantes de uma das línguas eslavas 
trazida pelos imigrantes advindos das terras que haviam pertencido ao estado polonês, à época sob ocupação dos vizinhos. Junto com os seus falantes, a língua polonesa chegou ao Brasil no ano 1869, na ocasião da tentativa de fundação da primeira colônia polonesa em Brusque, Santa Catarina. As desavenças com os alemães, as novas e as antigas, trazidas das terras natais, fizeram com que os primeiros poloneses no Brasil buscassem seu novo lar no Paraná, principalmente nos arredores de Curitiba, onde no ano 1871 foi fundada a primeira colônia polonesa propriamente dita. Estima-se que, até a eclosão da Primeira Guerra Mundial, 115 mil poloneses, na sua maioria camponeses, estabeleceramse no território brasileiro (KULA, 1981). O período posterior, principalmente até o início da Segunda Guerra, trouxe às terras brasileiras cerca de 41 mil poloneses (MAZUREK, 2019).

Apesar de sua pequena contribuição numérica no mar de imigrantes europeus que atracaram às margens brasileiras durante todo esse período (somente $3 \%$ de todos os imigrantes eram poloneses, segundo dados do IBGE, 2000), a presença polonesa na região Sul foi expressiva. Por exemplo, no Paraná, os poloneses forneceram o maior contingente entre todos os grupos de imigrantes, atingindo na época o patamar de $48 \%$ entre os novos moradores estrangeiros desse estado (MARTINS, 1941, p. 52-53 apud IANNI, 1987, p. 172).

Citados os números, é necessário enfatizar a sua imprecisão causada pela situação política das terras polonesas e seus moradores durante o período analisado. O estado polonês, existente desde o ano 966, foi ocupado, no século 18, por três grandes impérios, Prússia, Rússia e Império Austro-Húngaro, o que levou ao seu desaparecimento do mapa mundi por 123 anos: desde o ano 1795 até o ano 1918. Em consequência disso, as pessoas da etnia polonesa, ao chegar ao Brasil, possuíam somente documentos emitidos pelos ocupantes do território polonês, os quais muitas vezes não mencionavam a origem polonesa dos seus portadores. Os números oficiais de imigrantes poloneses no Brasil até o ano 1914 podem ser, portanto, subestimados. Dito isso, o contingente das pessoas munidas com o passaporte polonês e vindas ao Brasil nos anos 1918-1939 pode exceder o número real de poloneses, pois cerca de $70 \%$ delas eram representantes de minorias 


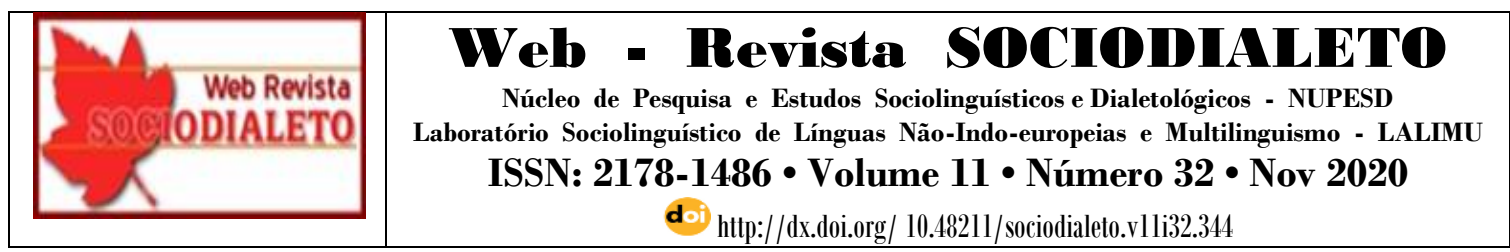

nacionais, principalmente de ucranianos e judeus (MAZUREK, 2019), integradas ao estado polonês no momento de seu reestabelecimento nos anos seguintes ao fim da Primeira Guerra Mundial.

O objeto desta pesquisa são as atitudes linguísticas dos moradores da Colônia Dom Pedro II (Paraná) ${ }^{1}$ - uma das primeiras colônias polonesas constituintes do assim chamado "cinturão verde", cuja função nos anos 1870 era o fornecimento de alimentos à capital paranaense (WACHOWICZ, 1976). A pergunta da pesquisa é como os descendentes de poloneses nessa comunidade percebem a língua polonesa e como as suas crenças e opiniões referentes a ela se relacionam com as decisões linguísticas por eles tomadas, tais como a transmissão da língua para os filhos e os esforços na manutenção da língua dos ancestrais na comunidade.

Na primeira parte do presente artigo apresentaremos o aporte teórico norteador deste trabalho, referente às atitudes linguísticas e à sua possível relação com o processo de manutenção/substituição das línguas minoritárias. Em um segundo momento, será exposta a metodologia adotada na pesquisa, seguida da apresentação dos resultados, composta das atitudes referentes à língua polonesa padrão, à variedade falada na Colônia e, finalmente, à sua manutenção ou substituição. Nessa parte traremos também algumas comparações com as pesquisas já realizadas sobre esse assunto e analisaremos a possível relação entre as atitudes e os comportamentos para com a língua polonesa dos participantes da pesquisa.

\section{Atitudes linguísticas}

Atitudes, um dos conceitos centrais para Ciências Sociais, tornaram-se, a partir dos anos 1960, um dos importantes objetos de estudo da Sociolinguística. Como apontam

\footnotetext{
${ }^{1}$ FERREIRA, Alicja Maria Goczyla. A presença da língua polonesa na Colônia Dom Pedro II, Campo Largo - Paraná. Dissertação (Mestrado em Letras) - Programa de Pós-Graduação em Letras, Universidade Federal do Paraná, Curitiba, $2019 . \quad$ Disponível em: https://www.prppg.ufpr.br/siga/visitante/trabalhoConclusaoWS?idpessoal=57477\&idprograma=4000101 $\underline{6016 \mathrm{P} 7 \& \text { anobase }=2019 \& \mathrm{idtc}=1479}$
} 


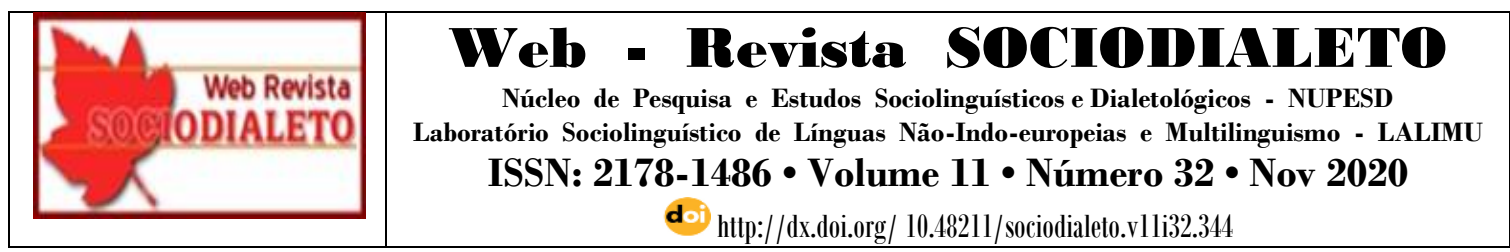

Cooper e Fishman, o motivo desse acontecimento é a complexidade dos fenômenos sociolinguísticos e, consequentemente, uma necessidade de adoção de "construtos hipotéticos preditivos igualmente complexos"2 (COOPER; FISHMAN, 1974, p. 5), os quais aumentem a compreensão desses fenômenos. Desde então, os estudiosos vêm testando e provando as suas hipóteses de que as atitudes linguísticas se relacionam com a mudança e a variação linguística, com a eleição de uma língua em sociedades multilíngues, com a alocação diferencial de códigos, com o uso e a competência linguística, com o sucesso na aprendizagem de segunda língua ou a conduta avaliativa de um professor dentro da sala de aula, entre outros (AGHEYISI; FISHMAN, 1970; BARCELOS, 2003; FINGER, 2008; GIBBONS; RAMIREZ, 2004). Existem também vários estudos que analisam as atitudes e as crenças linguísticas com relação às línguas de imigração no Brasil e a sua manutenção, tais como as pesquisas de Wepik (2017), Lara (2017) e Balthazar (2017), entre outras. Antes de nos aprofundarmos na definição das atitudes linguísticas, vale demarcar os conceitos de manutenção e de substituição linguísticas, os quais entendemos como extremos de um contínuo. Por manutenção entendemos a continuação do uso da língua tradicionalmente usada na comunidade (FASOLD, 1984), que no nosso caso é a língua polonesa trazida pelos imigrantes, a qual ao longo do tempo adquiriu alguns traços específicos, sob a influência do português brasileiro. Uma situação oposta, a de substituição, significa o aparecimento de uma nova língua (no nosso caso, o português) a qual vem a ocupar o lugar da língua "tradicional".

A grande variedade de pesquisas cria um campo propício a diferentes abordagens e, consequentemente, a diferentes conceituações do objeto de estudo. Neste trabalho, adotaremos a perspectiva mentalista, segundo a qual uma atitude é um "estado mental e neural de prontidão para resposta"”3 (AGHEYISI; FISHMAN, 1970, p. 138), em oposição da perspectiva comportamentalista, a qual identifica uma atitude com uma resposta visível a um estímulo, um comportamento. Mais especificamente, entenderemos sob o

\footnotetext{
${ }^{2}$ No original: “equally complex predictive hypothetical constructs”. Todas as traduções são da autora deste artigo.

${ }^{3}$ No original: "mental and neural state of readiness to respond".
} 


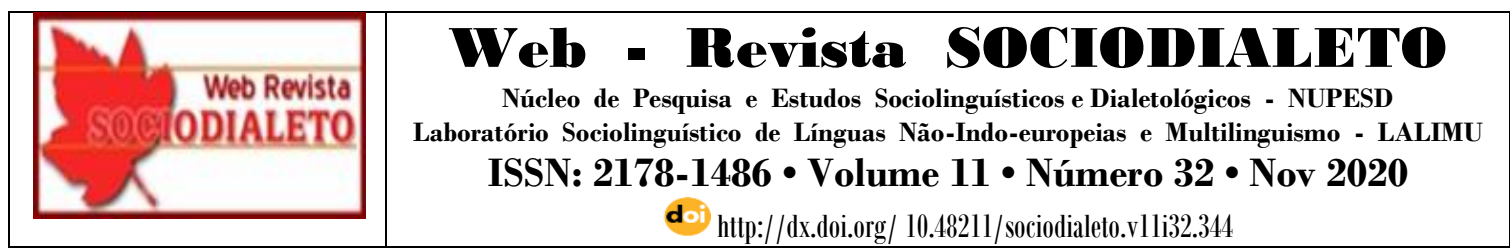

conceito de atitudes linguísticas "predisposições a responder a (falantes de) línguas específicas/estilos de fala e a situações linguísticas com um certo tipo de comportamento (linguístico)”“4 (VANDERMEEREN, 2005, p. 1.319).

A perspectiva mentalista, embora seja mais aplicada entre os sociolinguistas, traz consigo um problema metodológico, pois a atitude, a principal variável da pesquisa, não é diretamente observável. Como aponta Baker, "os pensamentos, o sistema de processamento e os sentimentos de uma pessoa são escondidos. As atitudes ficam, portanto, latentes e podem ser inferidas a partir da direção e da persistência do comportamento externo"5 (BAKER, 1992, p. 11). No caso de várias pesquisas sociolinguísticas, entre elas a nossa, a fonte da interferência das atitudes são os relatos dos informantes, os quais não precisam necessariamente refletir sobre os seus julgamentos mais sinceros. Por esse motivo, um dos papeis do pesquisador é criar uma atmosfera de abertura e de compreensão mútua durante as entrevistas, lembrando que as variáveis de pesquisa, tais como a identidade do entrevistador, a língua usada no questionário ou até a ordem das perguntas interferem nas reações dos informantes (VANDERMEEREN, 2005). No entanto, considerando essas dificuldades metodológicas, as atitudes inferidas nas pesquisas frequentemente são capazes de resumir, explicar e prever comportamentos (BAKER, 1992).

Tradicionalmente, as atitudes são concebidas como compostas de três elementos: o cognitivo, que se refere às crenças, aos pensamentos e ao conhecimento do objeto das atitudes; o afetivo, relacionado com os sentimentos e as avaliações; e o comportamental ou o conativo - a prontidão para ação, entendida também como uma intenção comportamental ou um plano de ação sob certas circunstâncias e no contexto dado (BAKER, 1992).

Quanto às crenças, contidas no componente cognitivo, vale enfatizar a sua relação

\footnotetext{
${ }^{4}$ No original: "predispositions to respond to (speakers of) specific languages/speech styles and language situations with a certain type of (language) behaviour."

${ }^{5}$ No original: "A person's thoughts, processing system and feelings are hidden. Therefore, attitudes are latent, inferred from the direction and persistence of external behaviour".
} 


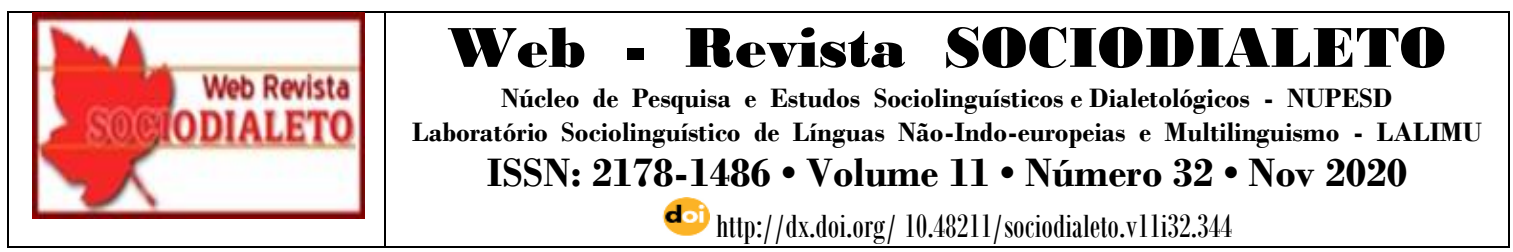

com o conhecimento. Neste trabalho comungaremos com as ideais de Dewey (2008) para o qual crenças:

cobrem todos os assuntos sobre os quais não temos certeza, no entanto somos suficientemente convencidos delas para agir com base nelas, e também os assuntos que agora aceitamos como certamente verdadeiros, como conhecimento, mas os quais podem ser questionados no futuro" (DEWEY, 2008, p. 116).

Essa acepção mostra a relação dinâmica no tempo entre a crença e o conhecimento, permitindo a adoção de uma perspectiva na qual as crenças dos informantes não são julgadas como verdadeiras ou falsas. Valendo-se da abordagem de Riley (1997) na Linguística Aplicada, podemos constatar que não se trata aqui de encontrar uma verdade, mas uma realidade "subjetiva" dos informantes, pois as suas decisões linguísticas são tomadas com base em suas crenças sobre sua realidade.

Acrescentemos ainda uma observação acerca da interrelação entre os componentes cognitivo, afetivo e conativo da atitude linguística, os quais podem estar em harmonia e, no entanto, nada impede que se contradigam. A seguinte fala de um dos nossos informantes, homem acima de 55 anos, demonstra uma relação entre as crenças (cognitivo) e os julgamentos (afetivo) do entrevistado:

(1) Também como eles [os imigrantes] eram de posses menores, de formação e de língua, vieram com o polonês totalmente deturpado. (...) $\mathrm{O}$ polonês está desaparecendo. Não serve para nada. É como você fosse estudar os dinossauros. (M3)

Com base em seu conhecimento sobre a condição social dos imigrantes (componente cognitivo), o informante expressa a sua avaliação negativa do valor da língua polonesa (componente afetivo), do qual poderia se tirar uma conclusão da sua rejeição da ideia de poder estudar a língua polonesa (componente conativo).

\footnotetext{
${ }^{6}$ No original: "It covers all the matters of which we have no sure knowledge and yet which we are sufficiently confident of to act upon and also the matters that we now accept as certainly true, as knowledge, but which nevertheless may be questioned in the future".

${ }^{7}$ Para a marcação dos informantes usamos a seguinte regra: $\mathrm{M}$ - masculino; $\mathrm{F}$ - feminino; 1 - de 18 a 35 anos; 2 - de 36 a 55 anos; 3 - acima de 55 anos.
} 


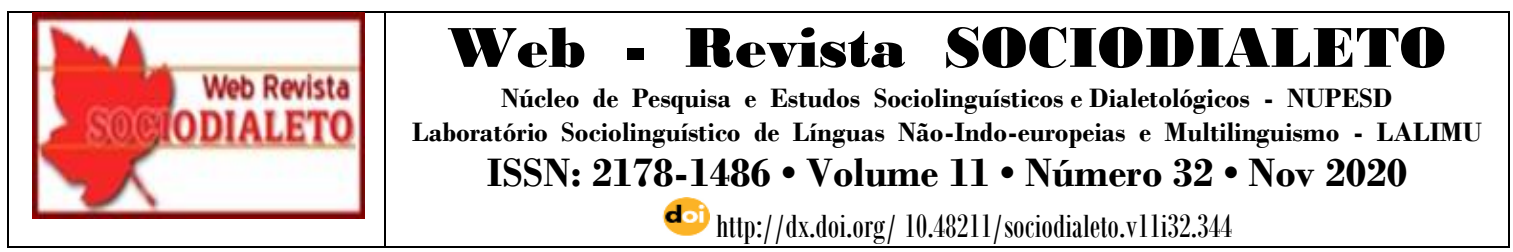

Observamos, portanto, uma situação de harmonia entre os elementos da atitude desfavorável do informante para com a língua dos ancestrais.

Por outro lado, o seguinte exemplo ilustra um descompasso entre a avaliação afetiva positiva e a descrição do comportamento linguístico do participante da pesquisa (homem, entre 36 e 55 anos):

(2) Língua polonesa é bonita. Todo sábado, na Canção Nova, da Terra Santa novena. Mas é tão lindo escutar como estão rezando! (...) Mas com o filho tudo em português, porque aqui não se fala polonês com ninguém. ${ }^{8}$

Apesar de uma forte avaliação favorável referente à beleza da língua e não obstante à regularidade com a qual o informante mantém contato com ela dedicando seus sábados para escutá-la, a fala indica também seu julgamento da falta de praticidade da língua polonesa e um consequente abandono dela nos contatos no dia a dia com os filhos (componente conativo).

Como observamos no excerto acima, a relação entre atitudes e comportamento não é simples, nem aparentemente lógica. Talvez, ainda mais surpreendente do que o fato de que o afeto para com a língua minoritária não seja suficiente para transmiti-la para seus filhos (fala 2) seja a postura do informante do excerto (1). Apesar de uma atitude claramente desfavorável para com a língua polonesa da Colônia e sua aprendizagem, o participante, alguns meses após essa entrevista, decidiu "estudar os dinossauros" e aderiu ao curso de língua polonesa ofertado na comunidade, tornando-se um dos alunos mais ávidos na turma.

Exemplos citados acima corroboram então a constatação de Ladegaard (2000), segundo o qual:

Aparentemente, é perfeitamente viável ter atitudes positivas com relação a uma variedade particular sem expressar essas atitudes no comportamento externo ou os comportamentos sociolinguísticos podem em alguns casos estar, não em concordância mas, em oposição

\footnotetext{
${ }^{8}$ Fala original: "Polski ładny język. Co sobota na Cancão Nova, da Terra Santa novena, ale jak ładnie słuchać jak po polsku się modlą! (...) Z dzieckiem wszystko po portugalsku, bo się nie góda z nikim po polsku tutaj."
} 


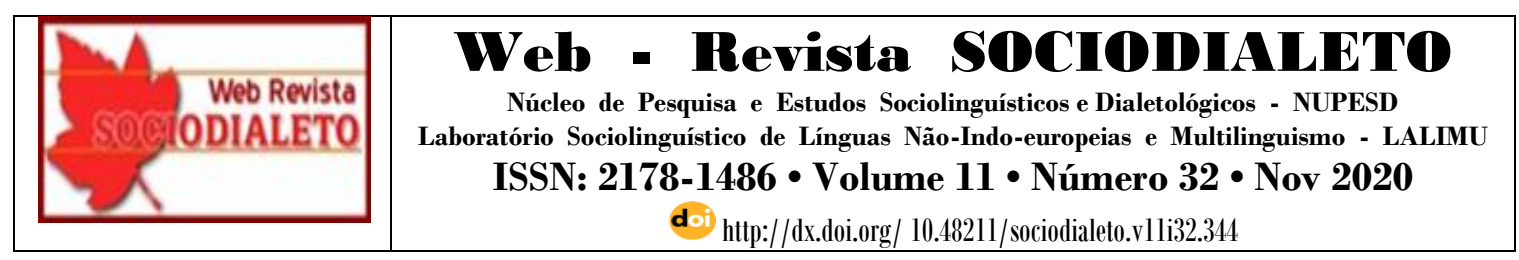

às atitudes se, por exemplo, alguém preferir uma variedade particular e não (puder) usá-la por vários motivos $^{9}$ (LADEGAARD, 2000, p. 230).

Portanto, é mister considerar que as atitudes não existem em um vácuo psicológico ou social. Elas são construídas socialmente, como resultado de interrelações com outros e com o ambiente (BARCELOS, 2003); exercem, em conjunto com fatores sociais, políticos e ideológicos, uma influência no comportamento; e têm seu significado social. Como é sabido, cada grupo é submetido a uma avaliação da sociedade com base em sua posição socioeconômica, cultural e/ou de poder. Aos grupos detentores de poder ou mais altos na escala socioeconômica costuma ser conferido o prestígio social. São esses grupos, que gozam de status, os quais regulam "as atitudes de valorização ou de rejeição às variedades de língua em uso, (...) ditam o que tem prestígio e status" (SILVA; AGUILERA, 2014, p. 714). Já que as atitudes com relação a uma língua são frequentemente confundidas com as atitudes referentes aos seus usuários, a língua falada pelo grupo dominante torna-se uma língua de prestígio e é considerada, também pelos falantes de línguas desprestigiadas, "mais bonita, mais expressiva, mais lógica" (GROSJEAN, 1982, p. 121). Em consequência disso, os falantes de línguas desprestigiadas, das "agramaticais, concretas e grosseiras" (GROSJEAN, 1982), podem tornar a ser objeto de preconceito linguístico, definido por Botassini (2013) como:

uma atitude negativa frente a determinado grupo linguístico sem razão aparente. Normalmente está voltado a grupos linguísticos que detêm pouco ou nenhum prestígio social, a minorias linguísticas, a grupos linguísticos que representam falares diferentes do falar daquele que avalia preconceituosamente o outro (BOTASSINI, 2013, p. 62).

Como se pode imaginar, tal preconceito frequentemente vem à tona nas pesquisas relacionadas com as línguas minoritárias, cujos falantes não raramente o incorporam em

\footnotetext{
${ }^{9}$ No original: “[I]t is apparently perfectly feasible to have positive attitudes towards a particular variety without expressing these attitudes in overt behaviours (...), or sociolinguistic behaviour may in some cases be, not in accordance but, in opposition to attitudes if, for example, someone favours a particular variety but cannot, or will not, use it for a number of reasons."
} 


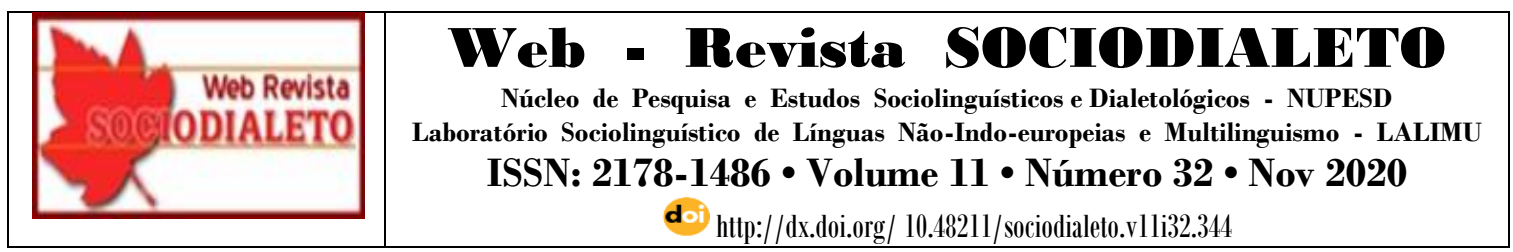

relação à sua própria língua, adotando uma atitude de insegurança linguística, perceptível nas falas como a seguinte, proferida em polonês:

(3) Falo, assim, um pouco. Não que nem vocês falam em polonês, assim gramaticalmente. Falamos assim... simples $^{10}(\mathrm{M} 3)$.

Obviamente, vários pesquisadores de atitudes em torno de línguas minoritárias perceberam essa e outras atitudes recorrentes nos relatos dos descendentes de imigrantes no Brasil e fora dele. Para otimizar o nosso espaço e para pôr a nossa investigação em contexto das pesquisas já existentes, os resultados de outras pesquisas serão brevemente discutidos e comparados no subtópico de descrição e análise dos dados.

\section{Metodologia}

Os dados que servirão de base para esta análise foram colhidos durante uma pesquisa sociolinguística realizada na localidade, cujo objetivo era a investigação da presença da língua polonesa na Colônia X (FERREIRA, 2019). Trata-se de uma comunidade rural, relativamente próxima à capital paranaense $(17 \mathrm{~km})$, cuja população de aproximadamente 690 pessoas é composta em $70 \%$ de descendentes de imigrantes poloneses, os quais fundaram a Colônia no ano 1876. Das nossas observações concluímos que o restante dos moradores é predominantemente de origem luso-brasileira e italiana. No entanto, a sua presença na comunidade, a qual resulta do aumento no número de casamentos exógamos, é relativamente recente e está visível principalmente a partir da última década do século 20.

Durante as entrevistas realizadas em polonês e em português, na forma de uma conversa semidirigida, com aproximadamente $10 \%$ da população da comunidade de origem polonesa (48 entrevistados), as crenças e as opiniões dos informantes acerca da língua polonesa padrão e da variedade usada na Colônia surgiram de modo espontâneo,

\footnotetext{
${ }^{10}$ No original: “Gódam, tak po trochu. Nie tak po polsku gramatycnie, jak wy gódocie. My tak na prosto gódamy”.
} 
embora a análise desse aspecto da sua relação com a língua dos ancestrais não tenha sido o objeto pretendido da pesquisa em andamento na época. A alta frequência com a qual esse tipo de julgamentos aparecia nas entrevistas nos fez perceber a importância de crenças e de afetos referentes à língua polonesa para os participantes da pesquisa, os quais demonstraram uma grande necessidade de expressar suas opiniões e sentimentos. Essa situação despertou nossa curiosidade quanto à relação entre as atitudes linguísticas dos moradores pesquisados e seu comportamento linguístico, suas decisões tomadas com relação à manutenção ou à substituição da língua polonesa.

Como indicamos, as expressões de atitudes linguísticas surgiram nas entrevistas de maneira espontânea, o que impossibilita o tratamento quantitativo dos dados obtidos; deixa, porém, espaço para uma pesquisa mais aprofundada de cunho qualitativo, com a categorização das respostas feita a posteriori e, portanto, possivelmente refletindo de alguma maneira as categorizações como concebidas pelas pessoas entrevistadas. $\mathrm{O}$ grupo dos informantes foi constituído por 24 mulheres e 24 homens de ascendência polonesa (de pelo menos um lado) divididos em três faixas etárias: 18-35 anos, 36-55 anos e acima de 55 anos. As entrevistas sociolinguísticas, realizadas na língua escolhida pelo entrevistado - polonês ou português - tratavam das questões linguísticas, tais como os contextos e frequência de uso da língua polonesa e as biografias linguísticas dos entrevistados. Foram abordados também os aspectos culturais e cotidianos de suas vidas, tais como a vida da comunidade, trabalho no campo, tradições e costumes, permitindo assim a obtenção de uma imagem mais detalhada da vida da Colônia e uma abertura maior dos participantes para o compartilhamento de seus sentimentos e pensamentos sobre a língua dos ancestrais e a sua condição de polono-descendentes.

A análise dos dados transcritos, realizada para este artigo, teve o foco nas atitudes linguísticas dos pesquisados referentes a três objetos principais: a língua polonesa padrão, a variedade presente na Colônia e a manutenção/substituição da língua polonesa. Após a categorização dos dados recebidos, buscamos relacionar as atitudes favoráveis, 


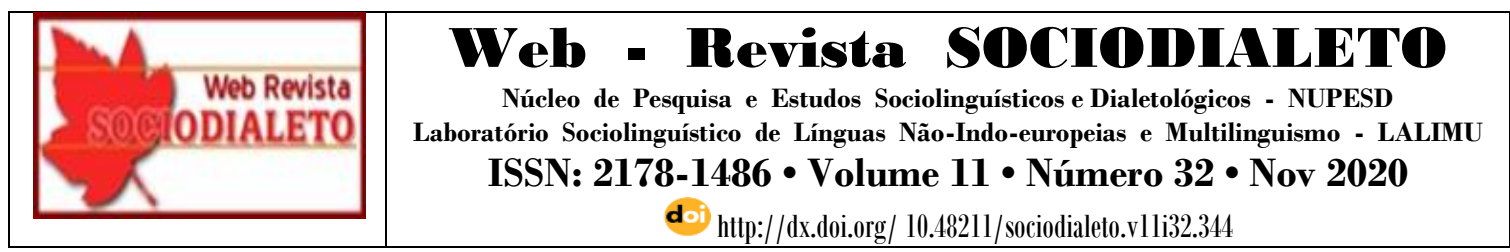

desfavoráveis ou neutras ${ }^{11}$ referentes às variedades da língua polonesa e sua manutenção com variáveis sociais (idade) ${ }^{12}$, o uso da língua polonesa, a competência linguística dos entrevistados e seus comportamentos, tais como a transmissão da língua dos ancestrais para filhos ou a participação do curso de língua polonesa na comunidade.

Para promover a melhor compreensão da situação linguística na comunidade pesquisada, resumiremos em seguida os resultados da pesquisa sociolinguística (FERREIRA, 2019), relevantes para o presente estudo.

\section{A presença da língua polonesa na Colônia $\mathrm{X}$}

Entre os objetivos da pesquisa referida (FERRIERA, 2019) estavam a verificação da situação de bilinguismo polono-português na comunidade e uma análise da competência ${ }^{13}$ na língua polonesa, relacionada com o fator idade, sexo e escolaridade dos moradores. Os resultados do estudo demonstraram que todos os 48 entrevistados podem ser considerados bilíngues, se adotarmos a acepção mais inclusiva de bilinguismo, visto como um contínuo de competências (VALDÉS, 2014). Para $68 \%$ dos pesquisados, a língua polonesa foi a primeira língua adquirida na infância, no entanto, essa porcentagem varia consideravelmente em função da idade dos indivíduos. Entre os informantes de mais idade (acima de 55 anos), 94\% falaram suas primeiras palavras em polonês, enquanto no grupo dos informantes abaixo de 36 anos foram somente 25\%. Quase metade dos entrevistados mais idosos considera o polonês a sua língua mais forte até hoje e $20 \%$ deles acreditam que nenhuma de suas duas línguas seja dominante. No grupo

\footnotetext{
11 Adotamos o raciocínio de Lara (2017) segundo o qual a neutralidade ou a indecisão também é uma manifestação de atitude.

12 Durante a análise dos dados foram consideradas também as variáveis sociais sexo e escolaridade, as quais, no entanto, não demonstraram uma relação significativa com as atitudes em estudo. Esse dado vai ao encontro dos resultados da nossa pesquisa da presença da língua polonesa nesta comunidade (FERREIRA, 2019), a qual confirmou que a única variável social relacionada de modo significativo com a competência dos informantes na língua polonesa é a idade.

${ }^{13}$ Neste artigo usamos o termo competência ou competência linguística no sentido mais amplo, o qual inclui tanto o conhecimento das normas gramaticais, como de normas socioculturais da comunidade em questão e a habilidade de adaptar a elas o uso linguístico.
} 


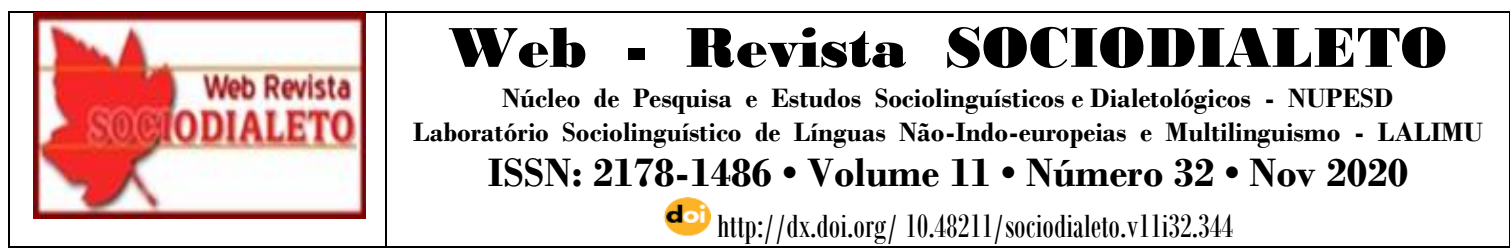

médio, a língua dos ancestrais está ainda presente como a dominante ou codominante junto com o português ( $42 \%$ no total). Todavia, entre os mais jovens todos sentem-se mais confortáveis falando o idioma português.

Esse quadro foi refletido também na autoavaliação da competência na língua polonesa dos informantes. $56 \%$ deles falam e entendem a variedade usada da Colônia bem ou muito bem (nível 3 de competência), 27\% entendem bem ou muito bem e falam pouco (nível 2) e 17\% entendem e falam pouco ou não falam (nível 1). A forte dependência entre a variável competência e a variável idade está ilustrada no Gráfico 1.

Gráfico 1 - Os níveis de competência dos informantes na língua polonesa por idade

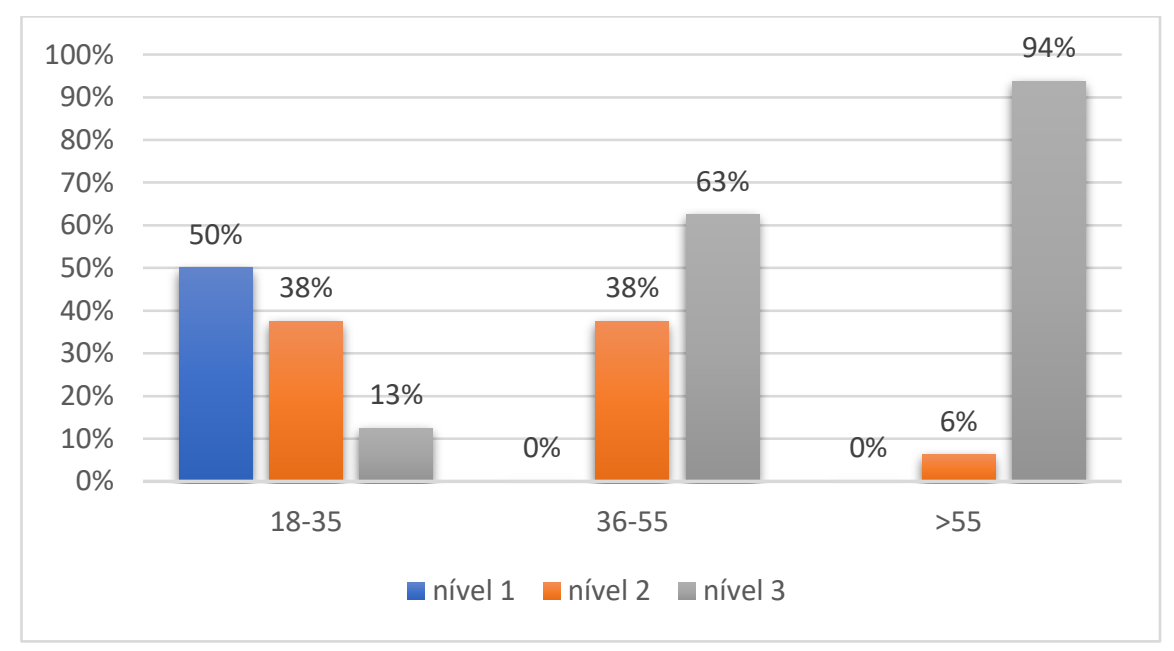

Fonte: FERREIRA, 2019, p. 145

Vale ressaltar que a análise multivariável, na qual testamos oito variáveis sociais $^{14}$, demonstrou que o fator faixa etária é o único significativo para a variação da competência na língua polonesa dos colonos pesquisados, o que indica certa inevitabilidade da substituição da língua polonesa na comunidade pelo português.

Acrescentemos ainda a informação sobre o uso da língua polonesa pelos pesquisados, dos quais $41 \%$ dizem falar o idioma diariamente ou frequentemente,

\footnotetext{
${ }^{14}$ As seguintes variáveis dependentes foram consideradas na nossa análise: sexo, faixa etária, escolaridade, atuação dentro/fora da Colônia, estado civil, com filhos/sem filhos, permanência fora da Colônia por mais de um ano, residência junto com os pais.
} 
enquanto 36\% não o fazem nunca. Como apontam Priestly, McKinnie e Hunter (2009), a língua é usada se os seus falantes são nela competentes. Os nossos resultados confirmam essa tese, pois entre os pesquisados com o maior nível de competência (o nível 3), 75\% falam a língua diariamente ou frequentemente, enquanto entre os informantes com o nível 2 essa porcentagem é nula. Preocupam também os contextos do uso da língua polonesa, praticamente limitados ao domínio de casa e determinados pelo interlocutor falante da língua. Quanto às taxas de transmissão, entre os informantes mais idosos que são pais, $56 \%$ transmitiram a língua aos filhos e $13 \%$ o fizeram parcialmente (somente a compreensão). Na faixa etária entre 36 e 55 anos esses números são de $8 \%$ e $23 \%$ e na faixa etária mais jovem - $0 \%$ e $29 \%$, respectivamente.

Os mesmos autores citados no parágrafo acima (PRIESTLY; MCKINNIE; HUNTER, 2009) se referem à manutenção de uma língua minoritária com a metáfora de um banquinho de três pernas para a ordenha de vaca. Se uma perna falhar, o banquinho cai. As pernas são: a competência na língua, o seu uso em vários domínios e as atitudes positivas com relação à língua a ser mantida. Apresentada brevemente a situação das duas primeiras pernas, passaremos então aos resultados do exame da terceira - as atitudes linguísticas.

\section{Descrição e análise dos dados}

A variedade da língua polonesa falada na Colônia $\mathrm{X}$, semelhante às variedades dessa língua usadas em outros lugares fora da Polônia ou variedades de outras línguas de imigração no Brasil, difere dos dialetos presentes hoje em dia na sua antiga terra-mãe. Em termos gerais, a variedade local da Colônia se caracteriza pela presença de:

- arcaísmos — por se tratar de assim chamada "velha emigração";

- regionalismos - pela origem camponesa dos fundadores da Colônia;

- germanismos, pois os imigrantes vieram dos terrenos ocupados na época pelo Império Austro-Húngaro; 


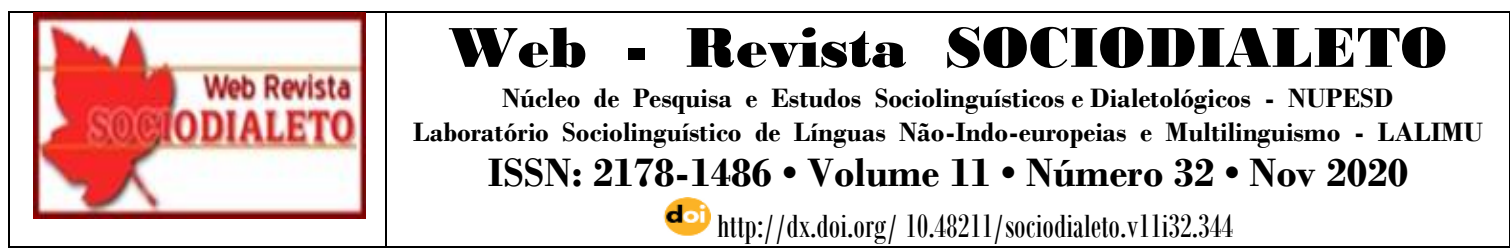

- fortes influências do português brasileiro resultantes de contato linguístico com essa língua durante período de 150 anos (FERREIRA, 2019, p. 118).

Um outro fenômeno frequente na fala dos moradores da Colônia é o code-switching (alternância de código), entendido aqui como inclusão de morfemas de duas variedades linguísticas no mesmo turno conversacional ou nos turnos consecutivos, o que é uma estratégia comum entre falantes bilíngues fluentes (MYERS-SCOTTON, 1998).

A grande maioria dos pesquisados está ciente de algumas diferenças entre a sua variedade e o polonês padrão, interpretando e explicando essas divergências de várias maneiras. Por isso, a língua dos ancestrais presente na Colônia é vista por muitos sob o prisma da língua polonesa padrão, tornando relevante para a nossa pesquisa uma análise das atitudes para com a variedade do outro lado do oceano.

\subsection{Atitudes linguísticas com relação à língua polonesa padrão}

O Quadro 1 resume as crenças (componente cognitivo) e as avaliações (componente afetivo) referentes à língua polonesa padrão (doravante LPP) indicando a quantidade de menções espontâneas durante as entrevistas. Perante a dificuldade em definir, em alguns casos, o objeto exato da avaliação (LPP ou polonês da Colônia), o Quadro 1 contém os julgamentos específicos para com a LPP e os gerais (os que não se referiam à língua da Colônia).

Quadro 1 - As crenças e as avaliações com relação à língua polonesa padrão

\begin{tabular}{|l|c|}
\hline \multicolumn{1}{|c|}{ Língua polonesa da Polônia é: } & Quant. das menções \\
\hline difícil para aprender, pronunciar e/ou entender & 13 \\
\hline diferente da falada na Colônia & 12 \\
\hline correta, gramatical, evoluída & 11 \\
\hline tem valor de uma língua estrangeira & 8 \\
\hline
\end{tabular}




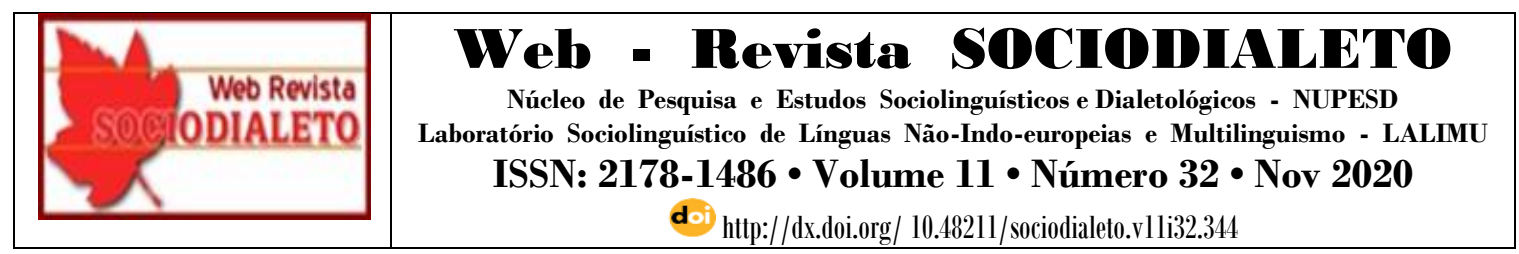

\begin{tabular}{|l|c|}
\hline bonita, emocionante & 7 \\
\hline não é muito diferente da falada na Colônia & 5 \\
\hline não tem um valor de língua estrangeira & 2 \\
\hline não é muito difícil & 2 \\
\hline
\end{tabular}

Como percebemos no Quadro 1, embora a avaliação mais frequente possa ser considerada negativa (cor vermelha) por indicar a dificuldade de acesso à língua polonesa, a maior parte das menções carrega consigo um julgamento positivo (cor verde) com relação a essa variedade do idioma. As menções classificadas por nós como neutras foram marcadas com a cor preta.

É importante ressaltar que a fonte da dificuldade da língua polonesa difere dependendo da faixa etária dos entrevistados. Enquanto para os mais jovens a principal queixa é a "pronúncia pesada" da língua polonesa, avaliação resultante de suas tentativas de repetir as palavras escutadas em casa, os informantes do grupo mais idoso enfatizam a sua dificuldade em aprender a ler e escrever a língua dos ancestrais. Nas palavras de um dos entrevistados:

(4) Ler? Muito mal. Essas letras polonesas têm muitas dessas perninhas. Eu não aprendi isso ${ }^{15}$ (M3).

Na segunda faixa etária (36-55), as únicas duas menções da dificuldade da língua polonesa referiam-se ao ritmo da fala dos poloneses na Polônia, experimentado durante as viagens para a terra dos tataravôs. Averiguamos, portanto, uma grande diferença nos níveis de intimidade com a língua entre os membros da faixa etária mais jovem e de outras duas. De um lado, muitos dos informantes abaixo de 36 anos enfrentam dificuldades típicas de aprendizes de uma língua estrangeira. Por outro, os restantes, quando percebem dificuldade na língua, levantam questões observadas mais comumente

\footnotetext{
${ }^{15}$ Fala original: "Cytać? Barz licho. Te polskie litery to mają duzo tych ${ }^{\dagger}$ ogonkuw. Ja sie nie naucył tego.”
} 


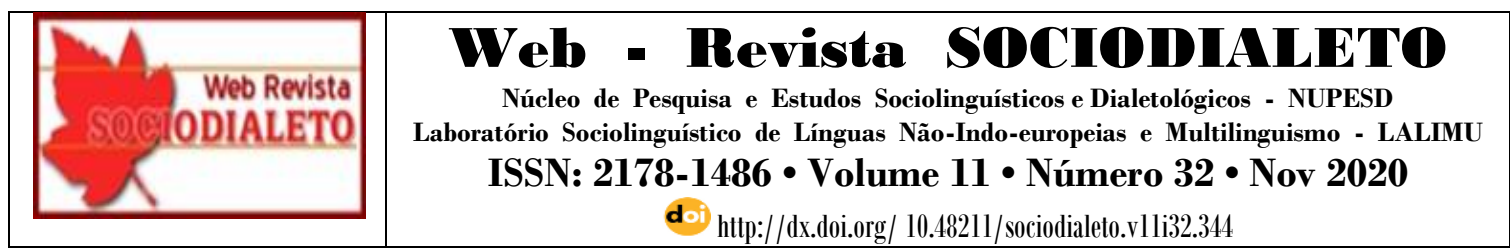

entre os falantes de línguas de herança (VALDÉS, 2014). É mister enfatizar que mesmo os poucos jovens com o nível de competência 3 ou 2 trazem à tona a dificuldade da língua polonesa percebida por eles.

Vale mencionar uma avaliação manifesta por uma entrevistada acima de 55 anos, a qual destoa dos julgamentos expressos pelas outras representantes dessa faixa etária. Foi ela a única nesse grupo a indicar uma dificuldade objetiva da língua polonesa para o seu processo de ensino/aprendizagem. Assim descreveu a sua tentativa de ensinar os netos:

(5) Até quando ensinava criança, em português eles pegavam bem, mas em polonês tava difícil. Essas palavra ... mais difícil. (F3)

Após uma análise mais aprofundada dos dados, observamos que a informante é a única entre as mulheres na faixa etária mais idosa que transmitiu a língua polonesa para os seus filhos somente parcialmente, os quais a entendem, mas não a falam. A dificuldade objetiva da língua indicada por ela pode ser, portanto, uma justificativa, talvez até inconsciente, do seu suposto fracasso na transmissão da língua ou um relato de uma real dificuldade experimentada por ela nas tentativas de ensinar os filhos e os netos.

Entre as questões válidas de um comentário encontra-se também certa dicotomia da percepção da LPP, ora como uma fonte potencial de capital simbólico (valendo se de conceito de Bourdieu, 1991), ora como um objeto de forte afeto. Essa primeira perspectiva surge nas observações presentes somente nos relatos do grupo mais jovem, segundo os quais o polonês "poderia agregar com as línguas" estrangeiras do seu repertório. Por outro lado, as expressões de um afeto forte para com a LPP apareciam com mais frequência na faixa etária média, o que ilustra a seguinte fala:

(6) Acho bonito polonês quando cantam. Pena que aqui no Brasil não é assim, né? Eu até choro, porque acho muito lindo. Mas não consigo aprender a cantar em polonês. (F2)

Novamente, a relação dos mais jovens com a língua polonesa se assemelha a uma relação com uma língua estrangeira, despida de sentimentos fortes, ao contrário da conexão que os seus pais ainda sentem com o idioma falado na Polônia. Chama atenção 


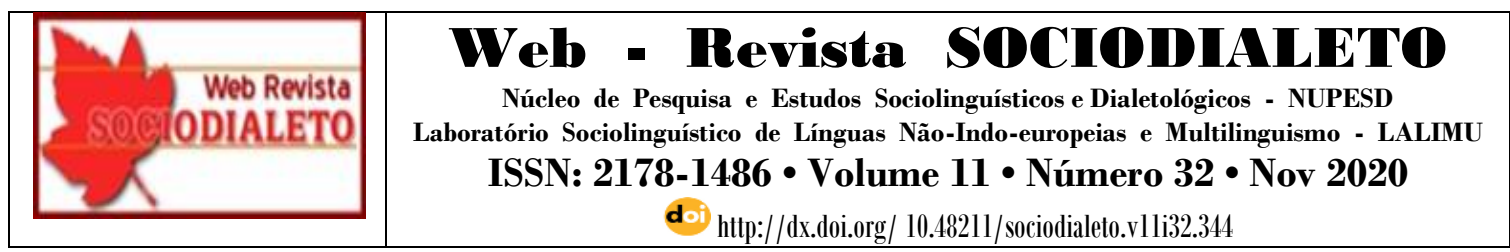

o fato de a entrevistada do excerto (6) não ser mais falante da variedade local e sentir emoção justamente no contato, no caso dela por rádio, com a variedade padrão dentro do contexto religioso, pois são os cantos religiosos que emocionam essa e outras pessoas entrevistadas na faixa etária média. Um terço das pessoas desse grupo procura ou recebe por celular canções religiosas e rezas da Polônia. Percebemos, então, uma possível ligação entre a língua polonesa e a vida religiosa dos entrevistados, na qual a língua dos ancestrais seria a depositária de uma parte da identidade religiosa de alguns moradores da Colônia. Essa indissociabilidade da língua polonesa e da religião, para os falantes das comunidades rurais do Paraná, já foi constatada também por alguns outros pesquisadores da área (cf. SIUDA-AMBROZIAK, 2015; DELONG; KERSCH, 2018).

A LPP e a sua presença na Polônia é vista por alguns entrevistados como algo bastante abstrato, algo que foge à sua compreensão plena. Parece ser difícil imaginar que uma língua tão parecida a deles, a qual conhecem somente na condição de uma língua minoritária, pode ser uma língua oficial de um país, o que ilustra a seguinte fala de um informante da faixa média com o nível de competência 3:

(7) Aqui é diferente do que lá? Deve ser só um pouco diferente. Lá falam tudo em polonês? Nossa, que engraçado! ${ }^{16}$ (M2).

Essa aparente impalpabilidade de uma língua polonesa lá longe não interfere na necessidade dos moradores de compará-la à sua variedade local. Nessa comparação, a língua padrão, a abstrata, costuma ser a vencedora nos quesitos de gramaticalidade e de correção, principalmente aos olhos dos informantes do grupo mais jovem e do grupo mais idoso. Já que essa avaliação da LPP resulta de uma avaliação desfavorável da língua falada na Colônia, passaremos agora à análise dessa segunda variedade.

\subsection{Atitudes linguísticas com relação à língua polonesa falada na Colônia}

\footnotetext{
${ }^{16}$ Fala original: „Tu jest inacej jak tam? Pewno troske ino inacej. Tam gadają wszystko po polsku? Nossa, que engraçado!"”
} 


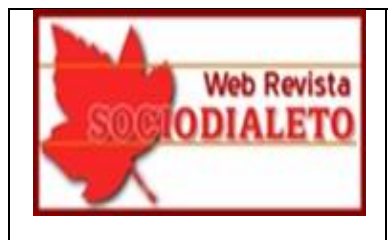

\section{Web - Revista SOCIODIALETO}

Núcleo de Pesquisa e Estudos Sociolinguísticos e Dialetológicos - NUPESD

Laboratório Sociolinguístico de Línguas Não-Indo-europeias e Multilinguismo - LALIMU

ISSN: 2178-1486 • Volume $11 ・$ Número 32 - Nov 2020

doi http://dx.doi.org/ 10.40211/sociodialeto.vlli32.344

Diferentes pesquisas de atitudes linguísticas com relação às línguas de imigração no Brasil registram uma grande frequência de juízos de valor depreciativos. Essas línguas costumam ser representadas por uma variedade dialetal, na maioria dos casos existente somente na oralidade, e são consideradas marginais e submissas à língua oficial, o português (ALTENHOFEN, 2004). Os termos repetidos nas pesquisas são "misturado", "entrecortado" (DELONG; KERSCH, 2018) "deturpado", "atrapalhado", (WEPIK, 2016), “errado", "sem gramática” (ALTENHOFEN, 2004; BALTHAZAR, 2017) como também "língua de colono" ou "um dialeto" no sentido pejorativo dessas expressões (FRITZEN, 2012). Obviamente, esse tipo de julgamentos não é exclusivo para a situação das línguas minoritárias no Brasil, sendo comum também para as variedades não padrão da língua portuguesa no Brasil (SILVA; AGUILERA, 2014) ou da língua polonesa na Polônia e fora dela, entre muitas outras.

Como observamos, alguns dos termos citados acima apareceram também na fala (1) proferida por um dos nossos informantes. No entanto, o leque de características atribuídas à variedade local pelos informantes se mostrou muito rico e mais variado do que o registrado no caso da variedade padrão. Por esse motivo, no Quadro 2 apresentaremos somente as crenças e as avalições mais frequentemente mencionadas durante as entrevistas.

Quadro 2 - As crenças e as avaliações com relação à variedade local da língua polonesa

\begin{tabular}{|l|c|}
\hline \multicolumn{1}{|c|}{ Língua polonesa falada na Colônia é: } & Quant. das menções \\
\hline errada/não gramatical/caipira/mais simples & 18 \\
\hline depositária da nossa cultura e origem & 14 \\
\hline diferente do polonês falado na Polônia & 13 \\
\hline arcaica/obsoleta & 12 \\
\hline misturada/abrasileirada & 12 \\
\hline um motivo de deboche e vergonha & 12 \\
\hline
\end{tabular}




\begin{tabular}{|c|c|}
\hline $\begin{array}{l}\text { Web Revista } \\
\text { 0.GLIALET0 }\end{array}$ & 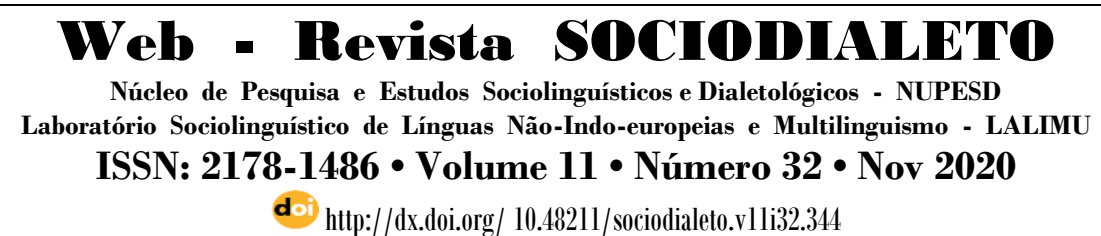 \\
\hline
\end{tabular}

\begin{tabular}{|l|c|}
\hline um meio de comunicação local eficiente & 11 \\
\hline um motivo de problemas com o português na escola & 10 \\
\hline $\begin{array}{l}\text { útil na aprendizagem do polonês padrão e outras } \\
\text { línguas estrangeiras }\end{array}$ & 10 \\
\hline bonita/gostosa de falar & 8 \\
\hline mais fácil do que o português & 7 \\
\hline $\begin{array}{l}\text { um motivo de orgulho (por conhecermos duas } \\
\text { línguas) }\end{array}$ & 6 \\
\hline
\end{tabular}

Da listagem apresentada acima, depreendemos um relativo equilíbrio nas quantidades das menções de avalições negativas (cor vermelha) e positivas (cor verde). Entretanto, é necessário considerar a espontaneidade dos relatos (falta de um questionário estruturado) e os pesos diferenciados dos julgamentos. Por exemplo, o fato de que alguns dos informantes enfatizem a beleza da variedade local pode não ser suficiente para compensar o sentimento de vergonha relacionado com o uso dessa língua, esse último argumento podendo ser decisivo quanto ao comportamento linguístico dos falantes.

\subsubsection{Atitudes favoráveis}

Iniciando a análise pelas avaliações favoráveis, observa-se que uma quantidade considerável dos informantes percebe a importância da língua polonesa, em particular da falada na Colônia, na constituição "da cultura e da origem” dos moradores da localidade, aqui entendida provavelmente como sua identidade, o que expressa a seguinte fala de uma entrevistada da segunda faixa etária:

(8) Porque os poloneses têm que falar polonês. Por que não vão falar? Se não, os poloneses vão acabar. Nós velhos falamos e depois esses jovens não vão falar. Assim não vai ter poloneses, só os brasileiros. ${ }^{17}(\mathrm{~F} 2)$

\footnotetext{
${ }^{17}$ Fala original: „Bo Polaki muszą gódać po polsku. Cego nie będą gódać? To sie Polaki skońcą. My stare gódamy, potem te młode nie bedą gódać. Nie bedą Polaki, same Brazyliany bedą."
} 


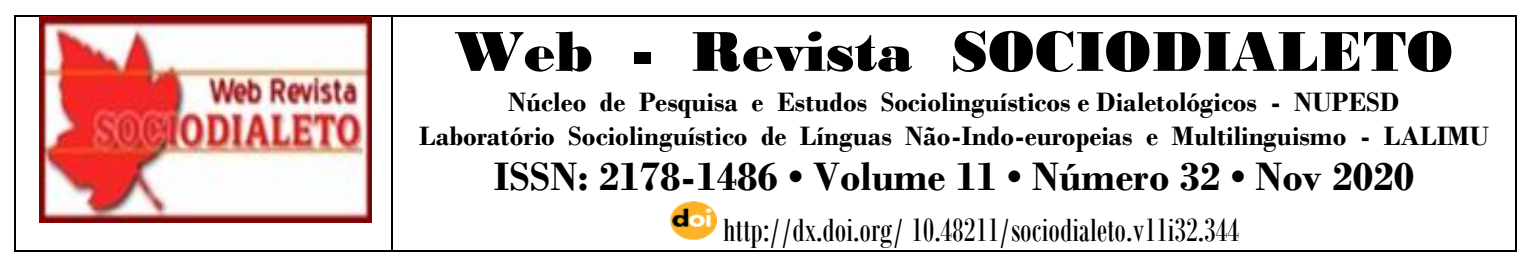

Não surpreende o fato de que essa avaliação surgiu principalmente nos relatos dos representantes do grupo de mais idade, no qual, lembremos, 94\% falam e entendem bem ou muito bem a variedade local (nível 3 de competência).

Ao analisar mais profundamente as respostas do grupo médio e do mais jovem, procuramos um padrão: as pessoas que acreditam na língua polonesa da Colônia como depositária da sua cultura teriam mais propensão a falarem essa língua e a transmitiremna para os seus filhos? Na faixa etária entre 36 e 55 anos, temos somente uma pessoa que realmente transmitiu a língua dos ancestrais para os seus filhos e duas que o fizeram parcialmente (filhos entendem polonês, mas não falam a língua). No grupo de pessoas dessa faixa que expressaram a sua ligação identitária com a língua polonesa identificamos: uma pessoa que transmitiu a língua; uma que o fez parcialmente; e mais duas com o nível de competência 3 que, apesar de não terem transmitido a língua, inscreveram seus filhos para o curso de polonês alguns meses depois das entrevistas. Portanto, é possível constatar que, no grupo pesquisado, a percepção do valor da língua dos ancestrais pode estar correlacionada com as atitudes e comportamentos mais favoráveis à manutenção da língua polonesa. No grupo mais jovem, esse padrão não aparece com tanta nitidez, embora os informantes que expressaram a importância da língua polonesa para a sua cultura sejam mais competentes na língua do que a média do grupo. ${ }^{18}$

As duas próximas avaliações favoráveis listadas no Quadro 2 são relacionadas com o valor prático da variedade local nas práticas linguísticas das pessoas pesquisadas. Os mais jovens atribuem à língua dos ancestrais um papel de uma língua intermediária na aquisição da LPP e outras línguas estrangeiras. Alguns deles acreditam que o seu conhecimento facilitaria na aprendizagem da língua polonesa da Polônia, o que confirmam os resultados da pesquisa de Kersch e Sauer (2010), segundo a qual, ao

\footnotetext{
${ }^{18} \mathrm{Na}$ faixa etária mais jovem $50 \%$ tem nível de competência 1 e $38 \%$ - nível 2. Entre os que mencionaram o valor cultural da língua polonesa uma pessoa tem o nível 3, duas - nível 2 e uma - nível 1.
} 


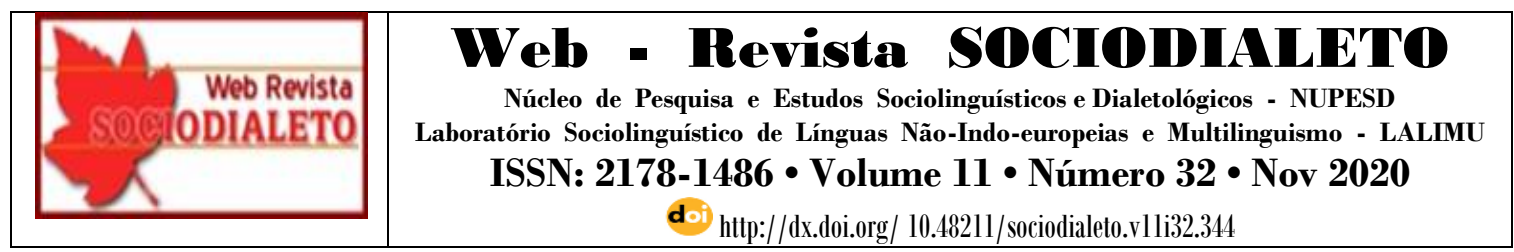

contrário do que se crê, ser falante de uma variedade dialetal, no caso o Hunsrückisch, pode auxiliar na aprendizagem da variedade padrão.

A segunda avaliação favorável que julgamos relevante é a de que a variedade local é um meio eficiente de comunicação dentro da comunidade, a qual foi expressa na maioria dos casos dos representantes da faixa etária média. Como resume uma das informantes:

(9) Se você falar do jeito que nois fala, entende tudo. ${ }^{19}$ (F2)

Entretanto, é importante observar que essas avaliações de certa praticidade da variedade local, aparentemente favoráveis, vêm à tona nos relatos dos informantes quase sempre como um contraponto para uma avaliação desfavorável, a saber, a da variedade ser errada e não gramatical. Citemos dois exemplos desse tipo de narrativas:

(10)Eu acho pena [de não ter aprendido a língua em casa]. Pelo fato que é alguma coisa, mesmo que tenha erros gramaticais, mas pelo menos tem uma segunda língua. Seria mais fácil aprender o polonês correto. (M1)

(11) A gente fala em polonês. A gente se entende. Pior quando vem algum gramatiqueiro. Se entende quando falam o polaco brasileiro. Mas quando vêm da Polônia... A gente fala assim... simples $^{20}(\mathrm{M} 3)$.

\subsubsection{Atitudes desfavoráveis}

Como vemos, aos olhos dos informantes, os atributos positivos da variedade local aparecem de certa maneira apesar de seus "erros gramaticais" e sua condição de ser mais "simples" do que uma língua padrão. As avaliações depreciativas, relatadas nas pesquisas citadas no início deste subtópico e muitas outras, surgem, portanto, também nesta pesquisa e são elas as mais frequentemente mencionadas pelos entrevistados na Colônia X. No entanto, vale ressaltar que os termos "língua de colono" ou "dialeto" não apareceram nas conversas, sendo as palavras "o polonês", “o polaco" ou "o polaco-

\footnotetext{
${ }^{19}$ Fala original: "Se você falar do jeito que nois fala, rozumi wszystko."

${ }^{20}$ Fala original: "Człowiek gódo po polsku. Wszyscy się rozumiemy. Gorzej, jak jaki gramatycyk przyjedzie. Rozumie, jak gódają polaco brasileiro. Ale jak z Polski... My tak na prosto gadamy."
} 


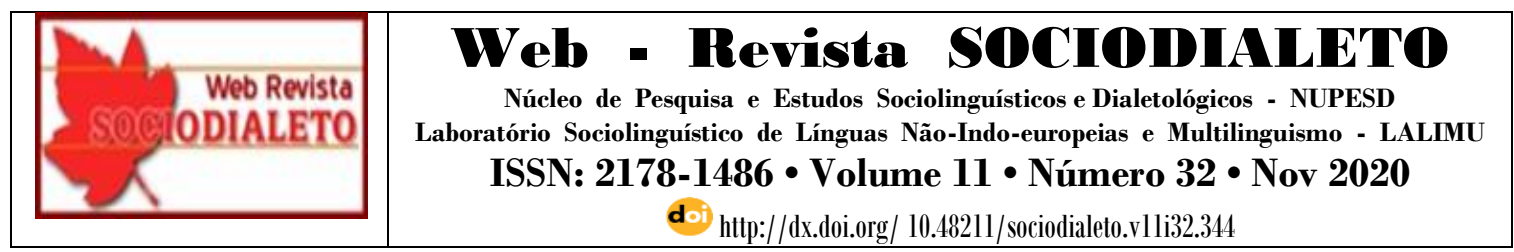

brasileiro" as denominações da variedade local usadas pelos entrevistados. Além disso, é importante explicar que a junção do atributo "caipira" na mesma categoria com “errado" e "não gramatical" se deve ao entendimento dos informantes sobre esse termo, resumido na seguinte fala:

(12) Nosso polonês é o polonês caipira. (...) Quando brasileiro não sabe falar o português certo, é brasileiro caipira. O nosso polonês também é caipira perto de vocês da Polônia. (M2)

Acrescentemos que essa percepção desfavorável da variedade local no quesito de sua correção é nitidamente mais comum nas faixas etárias média e a mais idosa. Os mesmos grupos chamaram também a variedade local de simplesmente diferente da LPP. É notável que as pessoas que descreveram a língua como diferente, atitude classificada por nós como neutra, não usaram para esse objetivo adjetivos "errado" ou "não gramatical" e vice-versa. É curioso que os dois grupos, os que usaram a palavra "diferente" e os que consideram a língua "errada", parecem demostrar comportamentos distintos com relação à língua. O primeiro grupo é composto por pessoas que dominam a língua no nível 3 (o mais alto) e transmitiram a língua para os filhos, exceto dois jovens que conhecem somente algumas palavras na língua dos ancestrais. O segundo grupo é constituído pelos informantes que falam pouco (nível 2) ou, se falam, não passaram a variedade para os seus filhos. Isso significa que nenhuma pessoa das $28 \%$ que transmitiram o polonês para os seus descendentes diretos descreveu a variedade local como errada, não gramatical ou caipira. Nesse caso percebemos, portanto, uma possível concordância entre os elementos cognitivos de atitudes linguísticas para com a língua polonesa da Colônia (o conhecimento ou a crença referente a sua gramaticalidade) e os elementos conativos, expressos no domínio da língua e a sua transmissão para as gerações mais novas.

Gostaríamos de chamar ainda a atenção para a observação dos informantes de que a variedade local seja "misturada" ou "abrasileirada". Essa avalição foi considerada desfavorável com relação a língua, pois nos relatos da maioria dos que a mencionaram foi ela compreendida como negativa, interpretação presente também em várias pesquisas de línguas minoritárias (WEPIK, 2017; HASSELSTRON, 2018). Todavia, um terço das 


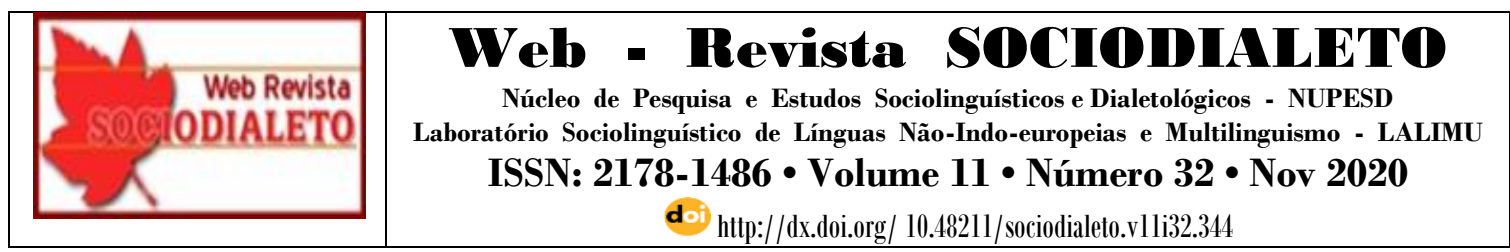

pessoas da nossa pesquisa usaram o termo no sentido positivo, sugerindo que justamente a mistura auxilia na compreensão da língua ou que ela é um resultado de um bom domínio de ambas as línguas. Esse último argumento foi nos contado por uma das informantes da faixa etária média em uma fala que por si só é um belo exemplo do fenômeno descrito por ela:

(13) Falo igual em polonês e em brasileiro. Tenho facilidade com os dois, por isso falo um pouco em polonês e depois mudo para o brasileiro, né ${ }^{21}$. (F2)

\subsubsection{A vergonha}

A próxima avalição negativa do Quadro 2, mencionada principalmente pelos informantes do grupo médio e do mais idoso, é o fato de que a língua dos ancestrais seja um motivo de vergonha e de deboche. "Vergonha" pertence certamente aos termos mais citados pelas pesquisas sociolinguísticas cujo objeto de estudo são as línguas de imigração. Na sua comparação das atitudes linguísticas de polono-, ítalo- e teutobrasileiros, Hasselstron (2018) faz uma constatação interessante de que entre os grupos pesquisados somente os polono-brasileiros sentem vergonha de usar a sua língua minoritária. Entretanto, a autora ressalta a especificidade da localidade pesquisada, na qual a etnia polonesa é minoria, como um dos possíveis motivos desse sentimento. Contudo, a atitude de vergonha para com a sua língua de herança foi constatada por inúmeras pesquisas de várias comunidades de origem europeia, por exemplo, os de descendência italiana (BALTHAZAR, 2016; FROSI; RASO, 2011), alemã (MARTINY, 2017) e ucraniana (SMAHA; LOREGIAN-PENKAL, 2019), além da polonesa (PEREIRA, 2017; WEPIK, 2017).

Percebamos que, dentro da categoria "a língua vista como um motivo de deboche e de vergonha”, existem vários tipos de atitudes e de comportamentos descritos pelos informantes. Entre os mais idosos predomina uma opinião feita com um tom acusatório

\footnotetext{
${ }^{21}$ Fala original: „Tylo gódam po polsku, co i po brazylijsku. Tenho facilidade com os dois. Za to po polsku gódam troche, wykręcam na brazylijsku, nie?
} 


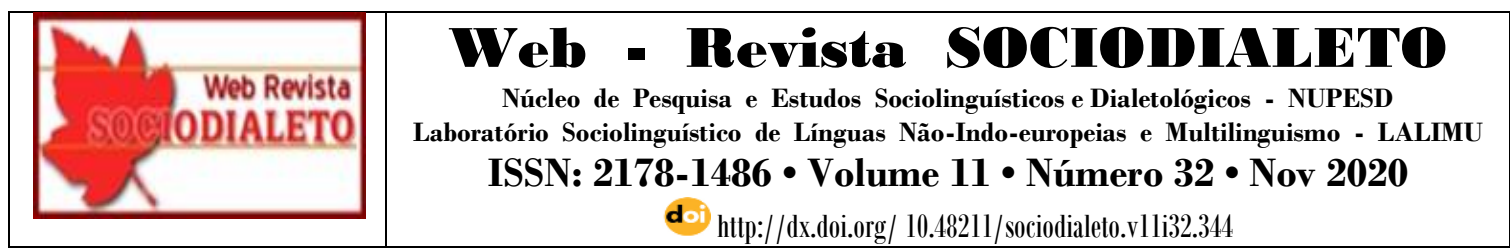

de que os mais jovens ou outros membros da comunidade não falam mais a língua por causa da vergonha de sua descendência. Perguntados por que alguém sentiria vergonha de ser polono-descendente, não sabem ou não querem indicar o motivo, resumindo a sua explicação à simples falta de vontade por parte dos acusados:

(14) Tem muitas primas que não vão falar polonês. Sabem, mas não querem. Não querem ser polonesas. Sentem vergonha. ${ }^{22}(\mathrm{~F} 3)$

Além do tom da queixa e da acusação presentes neste excerto, percebemos novamente a convicção da entrevistada quanto à conexão entre a língua e a identidade. Adicionemos ainda que esse mesmo tipo de acusação surge também nas falas das pessoas mais jovens, porém somente dessas que dominam e usam a variedade local.

É interessante observar que os mais idosos atribuem o aparecimento do sentimento de vergonha à chegada dos "brasileiros" na comunidade, a qual ocorreu junto com a abertura da escola às comunidades vizinhas, provavelmente no começo dos anos 1980. Todavia, mesmo nessa faixa etária aparecem relatos de deboches sofridos dentro da Colônia por ter transmitido a língua polonesa para os seus filhos. Chama atenção que essa experiência foi relatada somente pelas mulheres da faixa mais velha e a única mulher da faixa média que ensinou a variedade para os seus filhos. A origem do deboche não foi, portanto, somente externa à comunidade, o que comprova o seguinte relato:

(15) Os poloneses debocham. Quando meus filhos eram pequenos, foram para a escola, todos esses riam que não tem que ensinar em polonês, só em brasileiro. E agora todos esses que riam, agora todos eles querem [falar polonês]. ${ }^{23}$ (F3)

Durante as entrevistas com os informantes mais jovens foi marcante a repetição da narrativa referente a uma pessoa específica, hoje já um jovem adulto, o qual sofreu bullying na escola por dominar somente a língua polonesa e não o português nos

\footnotetext{
${ }^{22}$ Fala original: „Duzo jest półsiostrów, co nie bedą po polsku gódać. Umieją ino nie chcą. Nie chcą być Polacki. Sie wstydza.."

${ }^{23}$ Fala original: „Polaki sie śmieją. Jak moje dzieci takie małe były, posły do szkoły, to te wszystkie sie pośmiewali, ze nie trza ucyć się po polsku, bo... ino po brazylijsku. A teraz te wszystkie co sie pośmiewali, teraz one wszystkie kcą [mówić po polsku].
} 


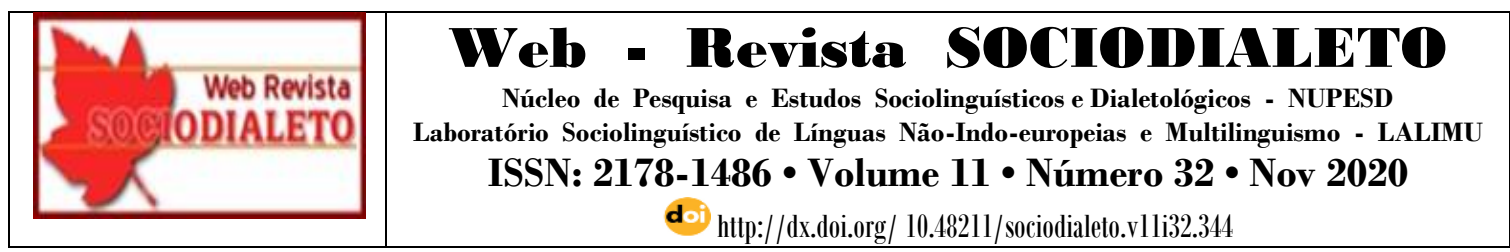

primeiros anos da sua educação escolar. Segundo os relatos dos informantes, os autores desse comportamento violento foram tanto as crianças fora da Colônia, de origens diferentes da polonesa, como as polono-descendentes. Acreditamos que não seja um acaso que, não obstante várias tentativas de contato, essa pessoa se recusou a conversar conosco, mesmo sem ser gravada.

A percepção da língua como um motivo de vergonha e deboche está fortemente ligada com as experiências escolares dos informantes, pois, para muitos, a escola foi o primeiro lugar onde a sua diferença dentro da sociedade brasileira lhes foi apresentada, frequentemente de uma maneira bastante dolorida. São os representantes da faixa etária média que consideram a língua polonesa um obstáculo na aquisição do português e uma causa de possíveis fracassos na escola - tanto na aprendizagem, como na vida social.

Foi essa geração, a primeira que obteve a educação realmente monolíngue na língua portuguesa no ambiente etnicamente heterogêneo, a qual se tornou um objeto de preconceito linguístico. Indagados pelo motivo das expressões preconceituosas, tais como "polaco batateiro" ou "polaco burro", as quais guardam na sua memória até hoje, $65 \%$ de todos os pesquisados responderam que a sua fonte é o "sotaque polonês" ao falar português (FERREIRA, 2019, p. 176). Todos eles referem-se na verdade a um estigma específico, a saber, ao assim chamado por eles " $r$ puxado". Trata-se da realização do [r] fraco (tepe) no lugar do [r] forte (vibrante múltipla) ou fricativa /x/, traço comum também entre descendente de alemães e italianos (ALTENHOFEN; MARGOTTI, 2011).

É marcante que a internalização do preconceito linguístico pelos próprios falantes da Colônia está presente em todas as faixas etárias, o que mostram os trechos citados abaixo:

(16) Nois se cagava de rir! Quando um polaco vai falar português, tem um sotacão! (M1)

(17) Aqui já pessoal fala mais civilizado, que nem a gente, mas se pegar mais pro lado de Araucária, eles ainda falam, no brasileiro no caso, aquele estilo polonês, meio assim de falar meio errado. Mas eles falam bem estilo como se tivessem em casa falando polonês direto. (M2) 


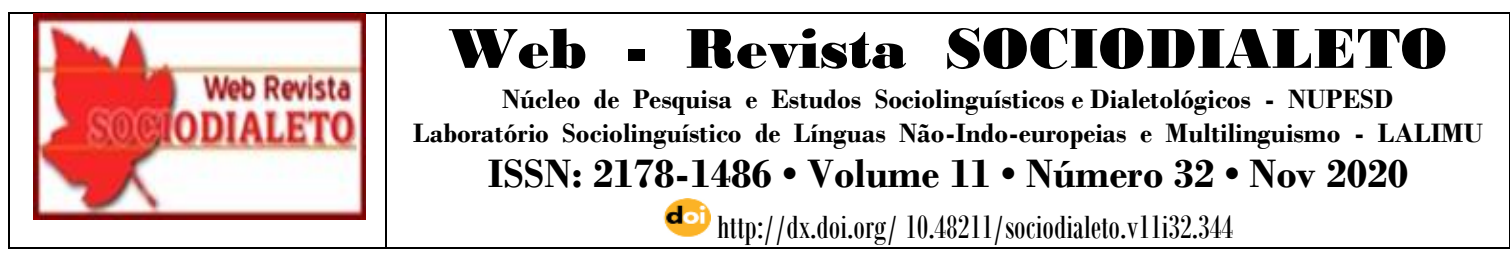

(18) Por isso que a gente não ensinou mais os neto a falar. (...) Não sei se era, talvez um pouco de vergonha, né, porque chamavam de polaco burro, tipo assim, falava feio, não falava que nem o brasileiro falava bonito" $(\mathrm{F} 3) .^{24}$

Enquanto os acima de 55 anos expressam ainda o seu orgulho de saber falar polonês e de ser bilíngue, pois "é uma honra conhecer duas línguas", o que demonstra a existência de um prestígio encoberto (LABOV, 1972) da variedade, os seus filhos admitem ter tido problemas para acompanhar os conteúdos da escola e ter optado pelo abandono da língua polonesa no momento da chegada dos filhos para que esses não repetissem o destino dos seus pais.

A ideia de que o conhecimento de uma língua interfere negativamente na aprendizagem de outra já foi refutada por várias pesquisas: a ideia de que a língua de imigração seja responsável pelo fracasso escolar de descendentes é chamada por Altenhofen (2004) de nada mais que um mito. Como apontam Giles e Billings (2004), os professores não são livres de preconceitos e a sua percepção da fala "errada" das crianças pode levá-los a fazerem inferências negativas com relação às suas personalidades e habilidades acadêmicas, o que, por sua vez, pode levar às profecias autorrealizadoras que prejudicam os alunos da fala não-padrão.

Dito isso, as experiências de se tornar bilíngue, descritas pelos informantes com o termo "ficar com a língua enrolada", e os preconceitos sofridos, resultaram em uma crença de que eles precisem, na educação de seus filhos, tomar uma decisão de silenciar a sua língua materna, mesmo dentro do ambiente domiciliar. Essa tendência, observada já anteriormente no caso de outras línguas de imigração (ALTENHOFEN; 2004), foi resumida nas seguintes palavras pela única mulher da faixa acima de 55 anos que não transmitiu a língua para os seus filhos:

(19) Quando os filhos foram para escola, tínhamos que conversar com eles em brasileiro. Devagar deixamos essa língua polonesa e tínhamos que conversar em casa em brasileiro. Hoje em dia tem que ser mais em português. Tem que dançar conforme a música ${ }^{25}$ (F3).

\footnotetext{
${ }^{24}$ Sobre algumas características da fala de descendentes de poloneses na língua portuguesa, veja, por exemplo, as pesquisas de Loregian-Penkal e Costa (2014) e de Mileski (2017).

${ }^{25}$ Fala original: „Jak dzieci posyły do szkoły, trzeba było rozmawiać po brazylijsku z nimi. Pomału się ostawiło tę mowę polską i musiało się po brazylijsku rozmawiać. [...] Hoje em dia tem que ser mais em português. Musi tańcować tak, jak grają."
} 


\begin{tabular}{|c|c|}
\hline $\begin{array}{r}\text { Web Revista } \\
\text { 0.C. ODIALETO }\end{array}$ & 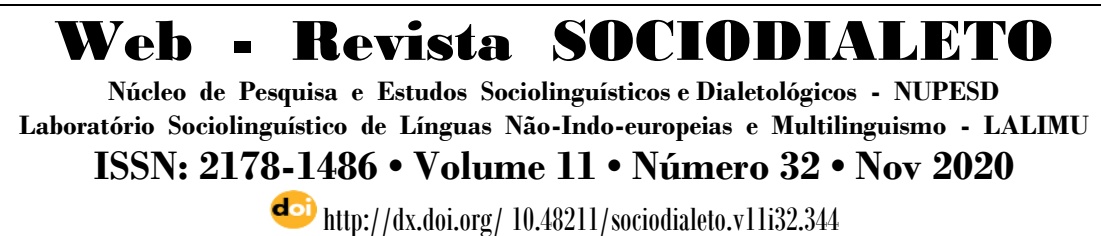 \\
\hline
\end{tabular}

Com isso, passaremos a discorrer sobre o último objeto das atitudes discutido neste trabalho - a manutenção da língua polonesa na Colônia.

\subsection{Atitudes em torno da manutenção da língua polonesa na Colônia}

Uma das conclusões da nossa pesquisa referente à mesma comunidade (FERREIRA, 2019) foi de que o visível processo de substituição linguística se deve principalmente aos fatores civilizatórios externos à Colônia, tais como a urbanização e a industrialização do entorno, as quais tiveram seu início no começo dos anos 1970. Esse momento coincidiu com os nascimentos das pessoas da faixa etária média - as que decidiram interromper o processo de transmissão da língua dos ancestrais que, até então, ocorrera por cerca de 100 anos. Altenhofen (2004) representa uma opinião semelhante quanto à importância dos processos civilizatórios na substituição das línguas de imigração:

A substituição da língua de imigrantes pelo português dá-se lentamente, por meio não de leis mas dos mecanismos sociais que ganham impulso com o desenvolvimento dos meios de comunicação de massa, o processo acentuado de urbanização e, consequentemente, a penetração maior do português através de elementos exógenos. Esse processo segue até hoje, em ritmo cada vez mais acelerado (ALTENHOFEN, 2004, p. 84).

Contudo, para os informantes são as suas próprias atitudes que têm o maior peso para a sobrevivência da língua na localidade. Quadro 3 apresenta as suas opiniões referentes aos fatores necessários para a manutenção da língua polonesa na Colônia.

Quadro 3 - Os fatores necessários para a manutenção da língua polonesa na Colônia segundo os informantes

A manutenção da língua polonesa depende...

Quant. das menções 


\begin{tabular}{|c|c|}
\hline $\begin{array}{l}\text { Web Revista } \\
\text { 0.GLIALET0 }\end{array}$ & 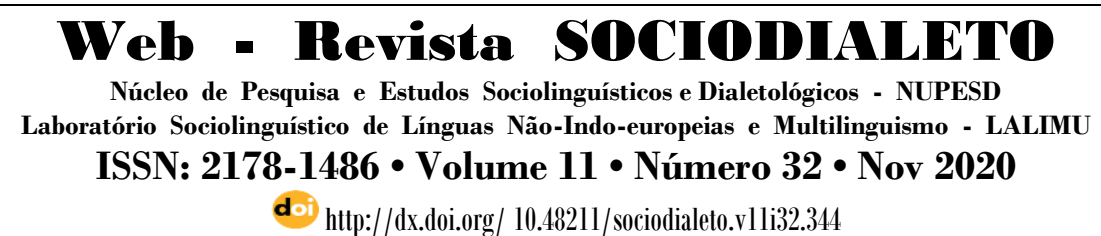 \\
\hline
\end{tabular}

\begin{tabular}{|l|c|}
\hline da vontade e da capacidade dos pais & 30 \\
\hline da prática constante na comunicação do dia a dia & 12 \\
\hline do incentivo externo, da escola, da igreja & 9 \\
\hline o mais importante é ensinar o português primeiro & 5 \\
\hline da vontade dos filhos & 5 \\
\hline do contato com os avós & 3 \\
\hline de fazer aulas de língua polonesa & 5 \\
\hline
\end{tabular}

De acordo com o Quadro 3, pontuamos a crença predominante dos entrevistados de que são eles mesmos, através de suas atitudes e seus comportamentos, que carregam responsabilidade pela preservação da língua minoritária na comunidade. Nos relatos, chama atenção a menção frequente da figura da mãe, tanto como aquela graças à qual os informantes preservaram a língua polonesa, como aquela que é responsável pela falta da transmissão. Essa observação corrobora as constatações de Delong e Kersch (2018), segundo as quais o ensino da língua polonesa nas colônias estava a cargo das mulheres. Em todos as faixas etárias, a aquisição da língua polonesa no ambiente natural dentro de casa foi indicada com mais frequência como a única ou a melhor maneira de garantir que as crianças conheçam a língua. Lembremos que foi desse modo que a língua foi transmitida até recentemente, porém, nenhum dos pais abaixo de 36 anos o fez. Alguns deles expressaram o seu arrependimento, fizeram mea culpa; outros justificaram as suas decisões pela baixa vitalidade da língua polonesa na Colônia, pela sua obsolescência. Muitos admitiram simplesmente não terem capacidade de ensinar seus filhos por não dominarem mais a variedade no nível suficiente.

As pessoas que já falaram a língua e a "perderam", o que aconteceu principalmente no grupo mais jovem, enfatizaram a necessidade da prática na 


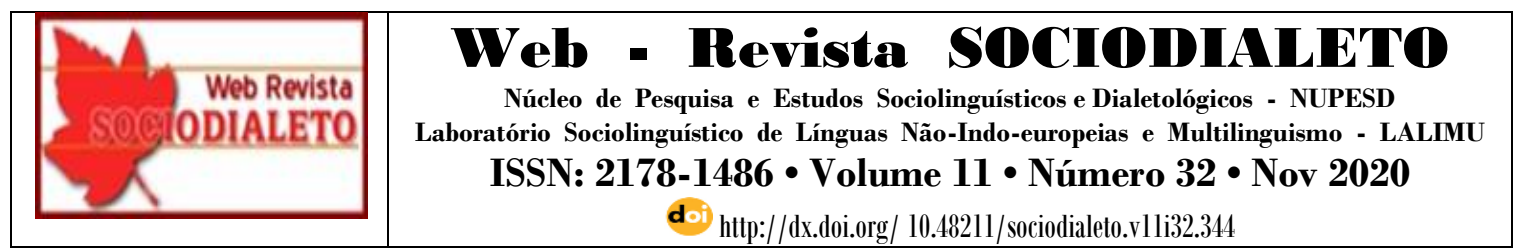

manutenção da língua, prática que, no caso deles, ocorria nos contatos com os avós ${ }^{26}$. Os mais velhos, por sua vez, percebem a necessidade da prática da leitura. $80 \%$ deles leem ou liam em polonês, porém, somente no nível básico. Maioria aprendeu a arte de leitura em polonês sozinho e acredita que a aprendizagem depende da boa vontade do aprendiz, como nos contou uma das informantes mais idosas:

(20) Meu marido lia. O pai comprava esses jornais poloneses, o avô lia e assim o meu marido aprendeu. Teve vontade. Se alguém gosta de ler, já vai pegar e lêe ${ }^{27}$. (F3)

É interessante que somente 3 pessoas indicaram uma possibilidade de fazer aulas de língua polonesa como uma ferramenta da manutenção da língua. No entanto, alguns meses após as entrevistas, quase todos os informantes que têm filhos na idade escolar os inscreveram para o curso ofertado na Colônia - primeira vez depois de mais de uma década. Além disso, quatro adultos das faixas média e mais idosa com o nível de competência 3 iniciaram o curso, incluindo o autor do excerto (1) para o qual estudar o polonês seria como "estudar dinossauros".

É necessário nos debruçarmos sobre a crença, relativamente comum entre os entrevistados, de que a língua portuguesa deve ser ensinada aos filhos como sendo a primeira. Enfatizemos que em muitas ocasiões as pessoas que expressavam essa opinião também acreditam que a língua polonesa pode ser mantida somente com a transmissão familiar. A seguinte fala ilustra esse paradoxo aparente:

(21) Minha mãe não sabia falar brasileiro. E ficava brava quando falavam. Mas nós falávamos assim: mas nós estamos no Brasil, temos que falar brasileiro, por causa dos filhos. ${ }^{28}$ Mas [para aprender polonês] deveria aprender de pequeno. Depois não sei se aprende. Como a gente pouco fala, menos que tudo, daí às vezes não escutam e não aprendem. (F3)

\footnotetext{
${ }^{26} \mathrm{O}$ papel dos avós na transmissão da língua de imigração foi apontado também nas pesquisas de Nunes (2018), no caso da língua polonesa, de Ribeiro, Lemke e Puh (2019) - língua ucraniana, e Lara (2017) Hunsrückisch, entre outras.

${ }^{27}$ Fala original: "Męż cytał. Pan łojciec kupował te gazety polskie, dziadek cytał i tak się moj męż naucył. Miał chęć za to. Jak ktoś lubi cytać, to się zoroz chyta i cyta."

${ }^{28}$ Fala original: "Minha mãe não sabia falar brasileiro. I zła została, jak by gódoć po brazylijsku. A my mówiły tak: mas my są w Brazyliji, my musimy mówić po brazylijsku, bo dzieci”. O restante da fala proferido em port.
} 


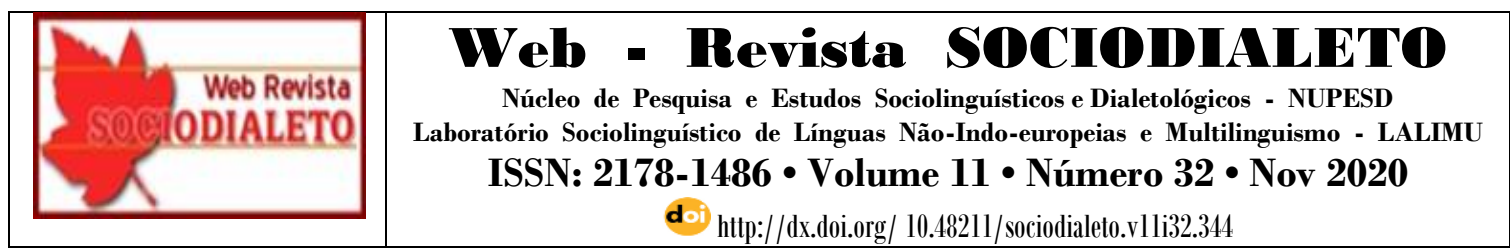

Percebemos aqui que, além do medo de a língua polonesa ser causadora das dificuldades dos filhos na escola, tema discutido no subtópico anterior, existia um forte argumento da brasilidade ou, valendo-se da terminologia de Altenhofen (2004), de mito nacionalista. Muitos pais da faixa etária média e alguns da mais idosa viram-se diante de uma decisão impossível: transmitir aos seus filhos a sua primeira língua, a sua língua materna, ou garantir que eles se sintam aceitos pela sociedade brasileira, que não sejam excluídos. Embora essa decisão tivesse que ser tomada pelas pessoas bilíngues, elas mesmas não percebiam uma educação bilíngue como uma saída possível desse impasse. Somente dois dos nossos informantes, da faixa média e que não têm filhos, expressaram uma convicção de que uma criança possa aprender duas línguas ao mesmo tempo. Embora alguns dos mais idosos enfatizem o orgulho que o conhecimento de duas línguas deve proporcionar, os mais jovens admitem entender a pressão social sob a qual seus pais se encontravam na época, pois:

(22) Mais antigamente não era bonito falar duas ou três línguas. Não era legal. (M1)

Apesar de uma consciência muito maior na sociedade hoje em dia quanto aos benefícios de educação bilíngue, a frase supracitada não deixa de continuar parcialmente verdadeira, pois o bilinguismo que dá ascensão social, também hoje, não inclui variedades dialetais de línguas de imigração. Como assevera Heller (2004):

É um bilinguismo no qual as variedades linguísticas envolvidas devem ser socialmente, regionalmente e geograficamente mais neutras possíveis. (...) um bilinguismo no qual os traços de contato nas práticas linguísticas são vistos como potencialmente perigosos ${ }^{29}$ (HELLER, 2004, p. 83).

Por isso, embora muitos dos informantes acreditem que a difícil tarefa de manter a língua polonesa na comunidade esteja somente sobre os seus ombros, é crucial lembrar

\footnotetext{
${ }^{29}$ No original: "it is a bilingualism in which the language varieties involved are meant to be as socially, regionally, and geographically neutral as possible. (...) a bilingualism in which traces of contact in language practices are potentially dangerous"
} 


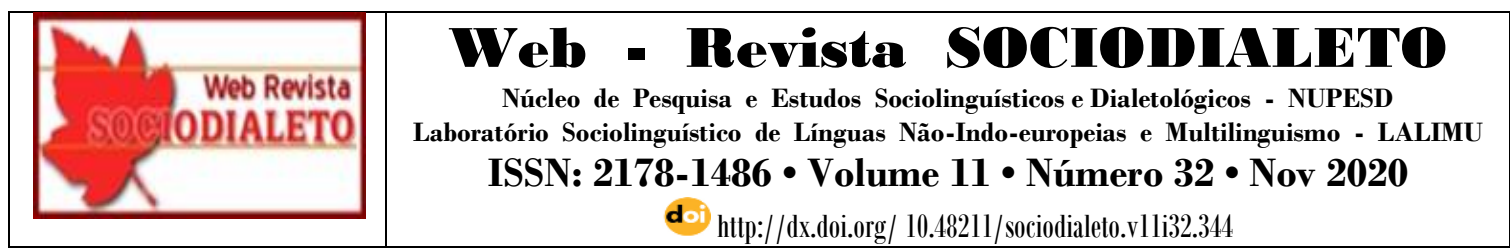

que as suas atitudes e, com elas, seus comportamentos e decisões linguísticas não pairam sobre um vácuo social, político ou ideológico. São eles um resultado de uma tentativa de fuga da marginalização e busca por uma ascensão social. Esta é possível somente seguindo as regras impostas pelas sociedades em um mundo das línguas que "não é somente um mundo de diferenças, mas de desigualdade"30 (BLOMMAERT, 2010, p.28).

\section{Considerações finais}

O objetivo deste artigo foi analisar as atitudes linguísticas para com a língua polonesa dos informantes da pesquisa realizada na Colônia $\mathrm{X}$ e observar a possível existência de uma relação entre as atitudes e as variáveis, tais como a competência na língua polonesa, a idade (fortemente correlacionada com a competência) e os comportamentos referentes à manutenção da língua dos ancestrais na localidade. Os comportamentos levados em conta na análise foram principalmente a transmissão da língua para os filhos e a participação do curso de língua polonesa organizado na Colônia.

A avaliação mais frequente da língua polonesa padrão é a de sua dificuldade, visível sobretudo na faixa etária mais jovem, a qual parece ter uma relação com a língua dos ancestrais muito semelhante a uma língua estrangeira. São também os mais jovens que percebem o polonês sob o prisma de mais uma língua que poderia agregar ao seu repertório linguístico e ao seu capital social.

O polonês padrão serve para muitos como um objeto de comparação com a variedade local. Com base nessa comparação, a língua polonesa falada na comunidade é julgada ser errada e não gramatical ou simplesmente diferente. Aqui foi observada uma regularidade: o grupo que descreveu a língua local como diferente, e não se valeu para isso de nenhum termo depreciativo, mostrou-se mais engajado na manutenção da língua polonesa (em termos de competência linguística, transmissão para os filhos e o incentivo

\footnotetext{
${ }^{30}$ No original: "The world of language is not just one of difference but one of inequality".
} 


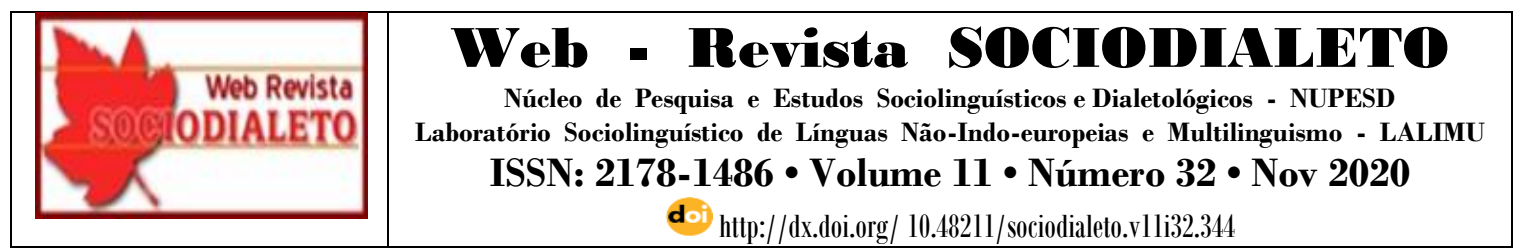

para a participação do curso) do que o grupo que se expressou de maneira desfavorável sobre a variedade local. Nenhum dos participantes da pesquisa que transferiu a língua para os seus descendentes diretos (28\% da amostra) se referiu a essa língua em termos pejorativos.

A segunda regularidade observada concerne a percepção da variedade local como depositária da cultura e da origem dos moradores da comunidade. Os participantes que mencionaram essa caraterística são mais competentes na língua e mais engajados na sua manutenção do que a média dos grupos etários aos quais pertencem. Percebemos, portanto, uma possível relação entre a atitude e o comportamento, a qual, no entanto, não permite constatação da existência de uma causação. Foi a atitude mais positiva com relação a língua que fez as pessoas transmitirem-na aos seus filhos ou foi a transmissão que gerou as avaliações mais favoráveis na tentativa de justificar todo o esforço e os deboches sofridos não só dos forasteiros, mas também dos “conterrâneos”? Infelizmente, esta pesquisa não responderá a essa pergunta.

Um fator que representou um papel crucial no processo de substituição da língua polonesa na Colônia foi certamente a crença de muitos dos informantes, principalmente da faixa etária média, de que a variedade local seja um motivo de vergonha e de deboche. Foi essa geração que, como primeira desde anos 1870, teve mais contatos com as pessoas de outras etnias dentro da escola na Colônia, o que resultou em surgimento de vários conflitos e preconceitos, inclusive os linguísticos. As dificuldades enfrentadas na escola, causadas supostamente pela interferência da língua polonesa adquirida como primeira na infância, foram, segundo os entrevistados, um dos principais motivos da interrupção da corrente de transmissão da língua polonesa na Colônia. A frequente crença de que, para sobreviver na localidade, a língua polonesa teria que ser adquirida dentro do lar na infância entra em conflito com a crença de que "os brasileiros têm que falar brasileiro" e de que o bilinguismo levará os filhos ao fracasso escolar.

Entre os pesquisados predomina a opinião de que eles mesmos são responsáveis pela preservação da língua na comunidade e, consequentemente, culpados pela substituição linguística que está ocorrendo diante dos seus olhos. No entanto, quando 


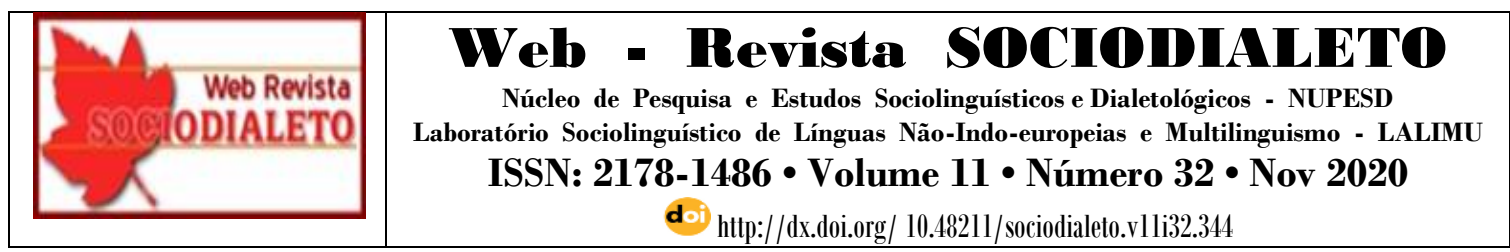

apresentados com uma oportunidade de aprender a língua em ambiente formal na comunidade reagiram entusiasticamente aderindo ao curso e incentivando os seus filhos, isso independentemente de suas avalições, expressas anteriormente referentes à aprendizagem formal de língua polonesa. A questão se o ensino de um polonês padrão pode preencher o vazio deixado pela língua apagada, silenciada, por mais pertinente que seja, não poderá ser abordada neste texto. No caso da Colônia X, a oportunidade de participar das aulas foi certamente percebida por uma grande parte dos moradores como uma chance de preenchimento dessa lacuna.

Concluindo, as atitudes linguísticas dos moradores da Colônia estão relacionadas, com força variável, à sua competência na língua polonesa, sua idade e seus comportamentos com relação à manutenção ou não da variedade local no seu dia a dia. Dito isso, essas atitudes e os comportamentos são resultado de um cenário social mutante e tornam-se um tipo de estratégia de fuga da marginalização dentro da sociedade, o que parece ter acontecido com a geração que decidiu não passar o polonês para os seus filhos. Se a língua continuar a ser percebida como arcaica e obsoleta, um obstáculo na ascensão social dos seus falantes, seria injusto culpar os descendentes pelo seu abandono. Não obstante, talvez uma solução seria a valorização do bilinguismo e da educação bilíngue - uma possibilidade pouco conhecida na Colônia. A maioria dos entrevistados, quando perguntados sobre a sua visão da presença da língua polonesa na Colônia em um horizonte de trinta anos não se mostrou muito otimista. Porém, talvez felizmente para a Colônia, as pesquisas mostram que a "previsão da morte de uma língua é um negócio arriscado" (WEINREICH, 1974).

\section{Referências}

AGHEYISI, R.; FISHMAN, J. A. Language Attitude Studies: A Brief Survey of Methodological Approaches. Anthropological Linguistics. v. 12, n. 5, p. 137-157, 1970.

ALTENHOFEN, C. V. Política lingüística, mitos e concepções lingüísticas em áreas bilíngües de imigrantes (alemães) no Sul do Brasil. Revista Internacional de Lingüística Iberoamericana, v. 2, n. 1 (3) p. 83-93, 2004.

ALTENHOFEN, C. V.; MARGOTTI, F. W. O português de contato e contato com as 


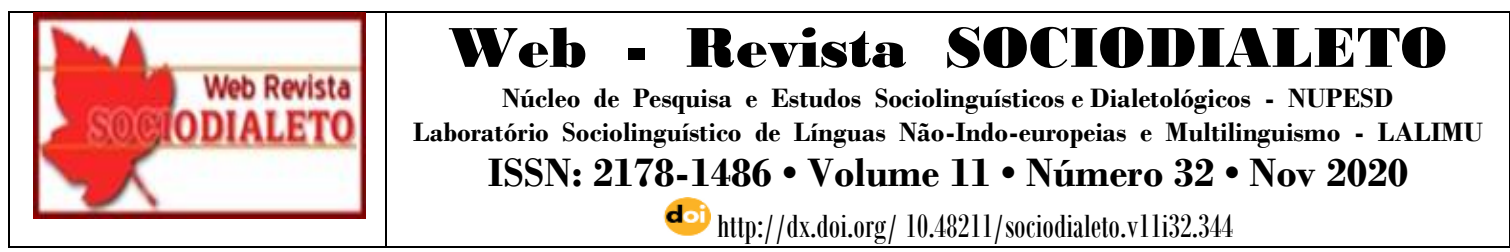

línguas de imigração no Brasil. In: MELLO, H.; ALTENHOFEN, C. V.; RASO, T. Os contatos linguísticos no Brasil. Belo Horizonte: Editora UFMG, 2011. p. 289-316.

BAKER, C. Attitudes and language. Clevedon, UK: Multilingual Matters, 1992.

BALTHAZAR, L. L. Atitudes linguísticas de ítalo-brasileiros em Criciúma (SC) e região. 2016. 302 f. Tese (Doutorado em Letras) - Programa de Pós-Graduação em Letras, Universidade Federal do Paraná, Curitiba.

BARCELOS, A. M. F. Researching Beliefs about SLA: A Critical Review. In: KALAJA, P.; BARCELOS, A. M. F. (Orgs.). Beliefs about SLA: New Research Approaches. Dordrecht: Springer, 2003. p. 7-33.

BLOMMAERT, J. The Sociolinguistics of Globalization. New York: Cambridge University Press, 2010.

BOTASSINI, J. O. M. Crenças e atitudes linguísticas: um estudo dos róticos em coda silábica no norte do Paraná. 2013. 220 f. Tese (Doutorado em Letras) - Programa de Pós-Graduação em Estudos da Linguagem, Universidade Estadual de Londrina, Londrina.

BOURDIEU, P. Language and Symbolic Power. Cambridge, MA: Harvard University Press, 1991.

COOPER, R.; FISHMAN, J. A. The study of language attitudes. International Journal of the Sociology of Language, v. 1974, n. 3, p. 5-19, 1974.

DELONG, S. R.; KERSCH, D. F. "O jeito polonês é um pouco diferente do brasileiro": Manifestações das identidades étnico-linguísticas dos descendentes de poloneses no Sul do Paraná. Antares: Letras e Humanidades, v. 10, n. 21, p. 37-54, 2018.

DEWEY, J. Essays and How we Think, Volume 8: 1933. Carbondale: Southern Illinois University Press, 2008.

FASOLD, R. The Sociolinguistics of Society. Introduction to Sociolinguistics. Vol.1. Oxford/New York: Basil Blackwell, 1984.

FERREIRA, Alicja Maria Goczyla. A presença da língua polonesa na Colônia Dom Pedro II, Campo Largo - Paraná. Dissertação (Mestrado em Letras) - Programa de Pós-Graduação em Letras, Universidade Federal do Paraná, Curitiba, 2019.

FINGER, L. Contexto multilíngüe: conduta avaliativa e atitudes lingüísticas. A influência de crenças e políticas. Contingentia, v. 3, n. 1, n.p., 2008.

FRITZEN, M. P. "Ia na escola alemã e de um dia pro outro fechou. E nós não sabíamos falar o português": refletindo sobre as políticas linguísticas em contexto de língua minoritária. Linguagem \& Ensino, Pelotas, v.15, n.1, p. 113-138, 2012.

FROSI, V. M.; RASO, T. O italiano no Brasil. Um caso de contato linguístico e cultural. In: MELLO, H.; ALTENHOFEN, C. V.; RASO, T. Os contatos linguísticos no Brasil. Belo Horizonte: Editora UFMG, 2011. p. 317-348.

GIBBONS, J.; RAMIREZ, E. Different Beliefs. Beliefs and the Maintenance of a 


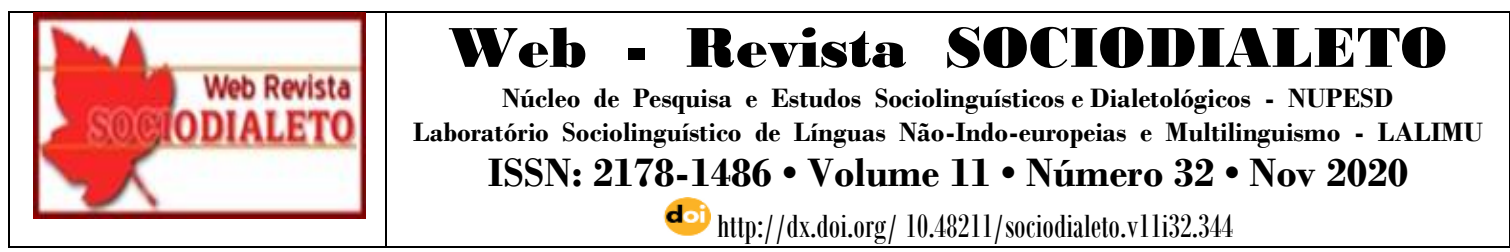

Minority Language. Journal of Language and Social Psychology, v. 23, n. 1, p. 99$117,2004$.

GILES, H.; BILLINGS, A. C. Assessing Language Attitudes: Speaker Evaluation Studies. In: DAVIS, A.; ELDER, C. (Orgs.). The Handbook of Applied Linguistics. Blackwell Publishing, 2004. p. 187-209.

GROSJEAN, F. Life with Two Languages: An Introduction to Bilingualism. Cambridge, MA / London, England: Harvard University Press, 1982.

HASSELSTRON, M. M. Línguas de imigração em contato com o português no Oeste Catarinense: crenças e atitudes linguísticas. 2018. 149 f. Dissertação (Mestrado em Letras) - Programa de Pós-Graduação em Estudos Linguísticos, Universidade Federal da Fronteira Sul, Chapecó.

HELLER, M. Globalization and the commodification of languages In: M. T. CABRÉ, M. T.; LORENTE, M; SOLÉ, E. Linguística Aplicada. Cicle de conferències i seminaris 98-00. Barcelona: Universitat Pompeu Fabra, 2004. p. 77-88.

IBGE. Brasil: 500 anos de povoamento. Rio de Janeiro, 2000. Apêndice: Estatísticas de povoamento. p.225. Disponível em: <https://brasil500anos.ibge.gov.br/estatisticasdopovoamento/imigracao-total-periodos-anuais>. Acesso em: 15 nov. 2018.

KERSCH, D. F.; SAUER, C.M. A sala de aula de alemão LE para falantes de dialeto: realidades e mitos. Linguagem \& Ensino, Pelotas, v.13, n.1, p.183-203, 2010.

KULA, M. Polonia brazylijska. Warszawa: Ludowa Spółdzielnia Wydawnicza, 1981.

LABOV, W. Sociolinguistic patterns. Philadelphia: University of Pennsylvania Press, 1972.

LADEGAARD, H. J. Language attitudes and sociolinguistic behaviour: Exploring attitude-behaviour relations in language. Journal of Sociolinguistics, 4/2, p. 214-233, 2000.

LARA, C.C. Variação fonético-fonológica e atitudes linguísticas: o desvozeamento das plosivas no português brasileiro em contato com o Hunsrückisch no Rio Grande do Sul, Brasil. 2017. 155f. Tese (Doutorado em Letras) - Programa de Pós-Graduação em Letras. Universidade Federal do Rio Grande do Sul, Porto Alegre.

LOREGIAN-PENKAL, L.; COSTA, L. T. Elevação da vogal/e/ na fala de descendentes de poloneses de Mallet-PR: uma análise variacionista. Web-Revista Sociodialeto. Vol. 4. $\mathrm{N}^{\mathrm{o}} 12$, p. 243-261, 2014.

MARTINY, F. M. Atitudes linguísticas em torno da língua de imigração e a sua (não) transmissão. Entrepalavras, Fortaleza, v. 7, p. 297-313, 2017.

MILESKI, I. Variação no português de contato com o polonês no Rio Grande do Sul: vogais médias tônicas e pretônicas. 2017. 323 f. Tese de Doutorado. Pontífica Universidade Católica do Rio Grande do Sul, Porto Alegre.

MYERS-SCOTTON, C. Code-switching. In: COULMAS, F. (Org). The Handbook of Sociolinguistics. Blackwell Publishing, 1998. Blackwell Reference Online. Disponível 


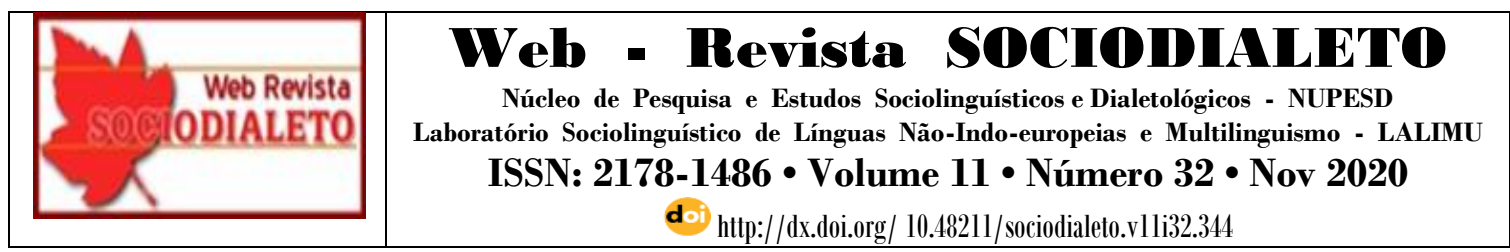

em: <http://www.blackwellreference.com/subscriber/tocnode>. Acesso em: 28 dez. 2007.

MAZUREK, J. O caráter específico da imigração polonesa para o Brasil. Polonicus: revista de reflexão Brasil-Polônia, Curitiba, Ano 10, n. 18, p. 34-57, 2019.

NUNES, R. B. O bilinguísmo português/polonês na constituição disposicional e na prática: perfis sociológicos de cinco descendentes de poloneses no município de Dom Feliciano/RS. 2018. Tese de Doutorado. 255f. Universidade Federal de Pelotas, Pelotas.

PEREIRA, I. A voz de polono-brasileiros: um contexto histórico sul paranaense. Working Papers em Linguística, 18(1), p. 23-45, 2017.

PRIESTLY, T.; MCKINNIE, M.; HUNTER, K. The Contribution of Language Use, Language Attitudes, and Language Competence to Minority Language Maintenance: A Report from Austrian Carinthia. Journal of Slavic Linguistics, v. 17, n. 1/2, p. 275-315, 2009.

RIBEIRO, H. A.; LEMKE, C. K.; PUH, M. Entre Estratégias e Táticas: A Manutenção de Línguas de Imigração em Irati, Paraná. Línguas \& Letras, v. 20, n. 46, p. 7-26, 2019.

RILEY, P. The guru and the conjurer: aspects of counselling for self-access. In: BENSON, P.; VOLLER, P. (Orgs.). Autonomy and independence in language learning. New York: Longman, 1997. p. 114-131.

SILVA, H. C. da; AGUILERA, V. de A. O poder de uma diferença: um estudo sobre crenças e atitudes linguísticas. Alfa, 58 (3), p. 703-723, 2014.

SMAHA, E.; LOREGIAN-PENKAL, L. Crenças que desencadeiam atitudes desfavoráveis à manutenção da língua ucraniana em Prudentópolis, Paraná. Interfaces, v. 10, n. 1, p. 151-161, 2019.

VALDÉS, G. Heritage Language Students. In: WILEY, T. G. et al. (Orgs.), Handbook of Heritage, Community, and Native American Languages in the United States: Research, Policy, and Educational Practice. Routledge, 2014, p. 27-35.

VANDERMEEREN, S. Research on language attitudes. In: AMMON, U. et al. (Orgs.). Sociolinguistics: An International handbook of the Science of Language and Society. Berlin/New York: De Gruyter, 2005. p. 1318-1332. v. 2.

WACHOWICZ, R. Ch. Órleans: um século de subsistência. Curitiba: Editora Paiol, Fundação Cultural de Curitiba, 1976.

WEINREICH, U. Languages in Contact. Findings and Problems. London-The HagueParis: Mouton \& Co, 1974 [1953].

WEPIK, F. F. Crenças e atitudes linguísticas de polono-brasileiros de Áurea/RS e Nova Erechim/SC: o uso dos termos de parentesco. 2017. 144 f. Dissertação (Mestrado em Letras) - Programa de Pós-Graduação em Estudos Linguísticos, Universidade Federal da Fronteira Sul, Chapecó. 


\begin{tabular}{|c|c|}
\hline $\begin{array}{l}\text { Web Revi } \\
\text { ODIALE' }\end{array}$ & 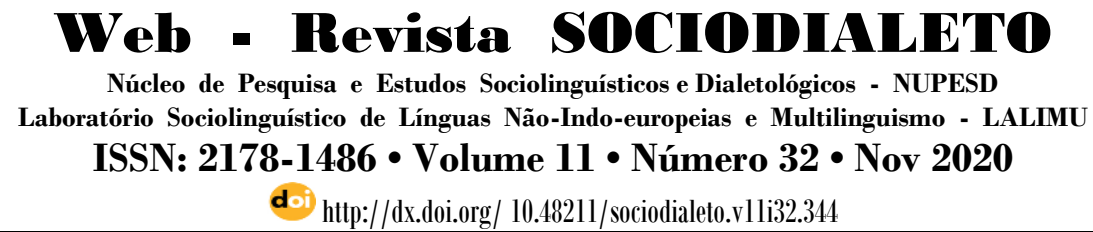 \\
\hline
\end{tabular}

Recebido Para Publicação em 29 de outubro de 2020.

Aprovado Para Publicação em 13 de dezembro de 2020. 